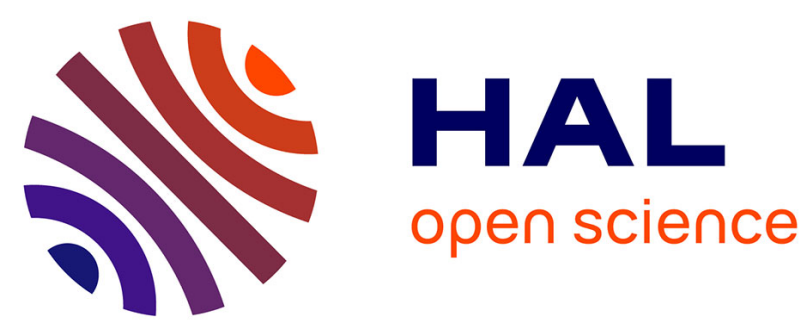

\title{
Investigation of the potential of the ICP-MS/MS for total and speciation analysis in petroleum fractions
}

Fabien Chainet, Alain Desprez, Sylvain Carbonneaux, Linda Ayouni, Marie-Laure Milliand, Charles-Philippe Lienemann

\section{- To cite this version:}

Fabien Chainet, Alain Desprez, Sylvain Carbonneaux, Linda Ayouni, Marie-Laure Milliand, et al.. Investigation of the potential of the ICP-MS/MS for total and speciation analysis in petroleum fractions. Fuel Processing Technology, 2019, 188, pp.60-69. 10.1016/j.fuproc.2019.01.013 . hal-02091325

\section{HAL Id: hal-02091325 \\ https://hal-ifp.archives-ouvertes.fr/hal-02091325}

Submitted on 5 Apr 2019

HAL is a multi-disciplinary open access archive for the deposit and dissemination of scientific research documents, whether they are published or not. The documents may come from teaching and research institutions in France or abroad, or from public or private research centers.
L'archive ouverte pluridisciplinaire HAL, est destinée au dépôt et à la diffusion de documents scientifiques de niveau recherche, publiés ou non, émanant des établissements d'enseignement et de recherche français ou étrangers, des laboratoires publics ou privés. 
1 Investigation of the potential of the ICP-MS/MS for total and speciation analysis in petroleum fractions

3 Fabien Chainet $^{1}$, Alain Desprez ${ }^{2}$, Sylvain Carbonneaux ${ }^{1}$, Linda Ayouni ${ }^{3}$, Marie-Laure Milliand ${ }^{3}$, 4 Charles-Philippe Lienemann ${ }^{1 *}$

6 1: IFP Energies nouvelles, Rond-point de l'échangeur de Solaize, BP3, 69360 Solaize, France

7 2: Agilent Technologies France, Parc Technopolis - ZA Courtaboeuf, 3 avenue du Canada, F891978 Les Ulis

9 3: Université de Lyon, Institut des Sciences Analytiques, UMR 5280 (CNRS, Université Lyon 1, 10 ENS Lyon) - 5, rue de la Doua, F-69100 Villeurbanne, France

\section{Abstract}

13 The capability of inductively coupled plasma tandem mass spectrometry (ICP-MS/MS) to achieve total concentration and speciation using direct injection of petroleum products after solvent dilution for severely interfered isotopes was demonstrated here with different applications cases. For the direct determination of heavy elements $(Z>70)$ in organic matrices, the ICPMS/MS was less sensitive than the ICP-HRMS. For light elements $(Z<40)$, the sensitivity was similar or better using ICP-MS/MS and for interfered elements ( $\mathrm{Si}, \mathrm{S}, \mathrm{Ca}, \mathrm{Fe}$ ), the use of the two quadrupoles combined to the octopole reaction/collision cell (ORC) with $\mathrm{He}, \mathrm{O}_{2}$ or $\mathrm{H}_{2}$ gave similar or better detection limits (LOD) than the ICP-HRMS in medium resolution. Comparable or better sensitivity were obtained replacing the $1.5 \mathrm{~mm}$ by the $1 \mathrm{~mm}$ injector diameter and especially for lighter elements $(Z<30)$ using the ICP-MS/MS. LOD in xylene were ranging from $0.004 \mu \mathrm{g} / \mathrm{kg}(\mathrm{V})$ to $0.9 \mu \mathrm{g} / \mathrm{kg}$ ( $\mathrm{Al}$ ) and appeared in the lowest values published in the literature using ICP-MS/MS in hydrocarbons. To demonstrate the performance of the ICP-MS/MS using direct injection of petroleum products after dilution in hydrocarbon solvent, three application cases were presented.

27 Sulfur at very low levels in reformates was successfully monitored in oxygen mode using the 28 oxide ion $\left({ }^{32} \mathrm{~S} \rightarrow{ }^{48} \mathrm{SO}\right)$. The background equivalent concentration (BEC) origin was attributed to solvent contamination by sulfur and was confirmed by ultra-violet fluorescence (UVF) method.

30 Using $\mathrm{H}_{2}$ for $\mathrm{Ni}\left({ }^{58} \mathrm{Ni} \rightarrow{ }^{58} \mathrm{Ni}\right)$ and $\mathrm{O}_{2}$ for $\mathrm{V}\left({ }^{51} \mathrm{~V} \rightarrow{ }^{67} \mathrm{VO}\right)$ as reactant gas, the direct injection ICP- 
31 MS/MS method easily confirmed $\mathrm{Ni}$ and $\mathrm{V}$ concentrations measured using wavelength dispersive 32 X-rays fluorescence (WDXRF) and allowed the determination of 14 elements in the asphaltene 33 fraction, with concentrations ranging from $0.3 \mathrm{mg} / \mathrm{kg}(\mathrm{Al}$ and $\mathrm{Pb})$ to $37.4 \mathrm{mg} / \mathrm{kg}$ for $\mathrm{Fe}$.

34 For speciation of $\mathrm{Ni}, \mathrm{V}$ and $\mathrm{S}$, gel permeation chromatography (GPC) hyphenated to ICP-MS/MS 35 is particularly powerful using $\mathrm{O}_{2}(2.5 \mathrm{~mL} / \mathrm{min})$ both for vacuum residue and hydrotreated (HDT) 36 vacuum residue. Contrary to GPC-ICP-HRMS where two injections of sample were required 37 (medium resolution for $\mathrm{S}$ and $\mathrm{V}$ and low resolution for Ni), GPC-ICP-MS/MS easily allowed the 38 acquisition of the 3 elements in one mode during the same run and considerably reduce the 39 analysis cost and time. Both for total and speciation analysis, the direct injection after solvent 40 dilution ICP-MS/MS method is a significant advantage and appealing in high-volume petroleum 41 laboratories.

42

43 Keywords : trace analysis; detection limits; speciation; petroleum products; polyatomic 44 interferences; ICP-MS/MS; ICP-HRMS; GPC; vacuum residue 45 46 


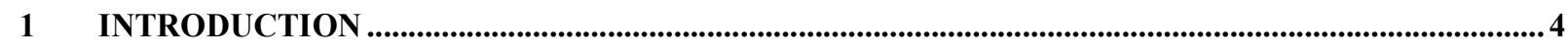

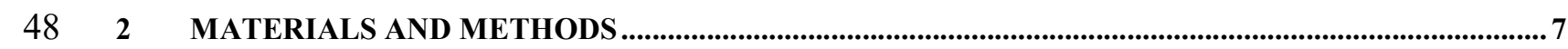

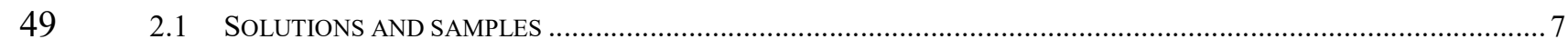

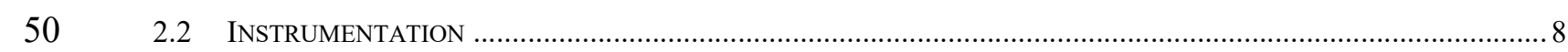

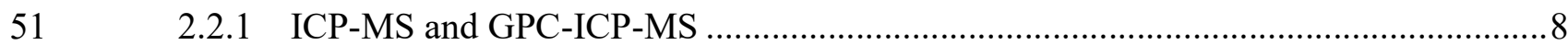

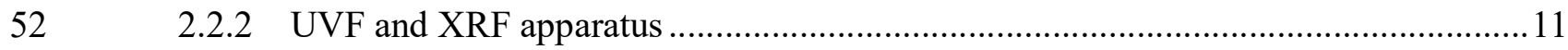

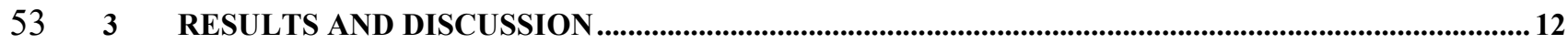

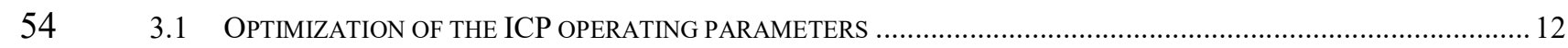

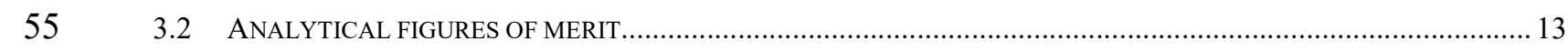

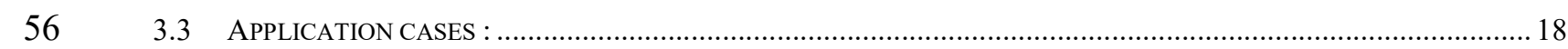

$57 \quad 3.3 .1 \quad$ Ultra trace sulfur determination in solvents using ICP-MS/MS ...........................18

$58 \quad 3.3 .2$ Trace elemental composition of Asphaltenes by ICP-MS/MS ...............................19

$59 \quad 3.3 .3$ Speciation of Ni, V and $\mathrm{S}$ in heavy petroleum cuts by GPC-ICP-MS ...................21

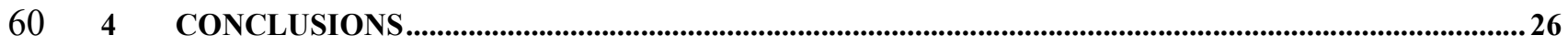

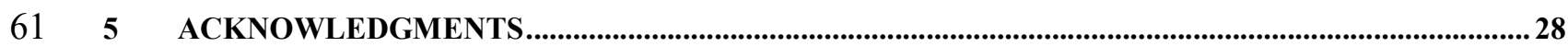

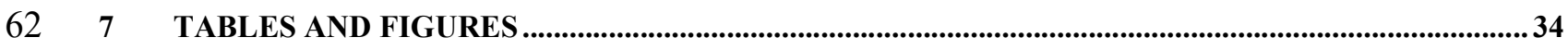

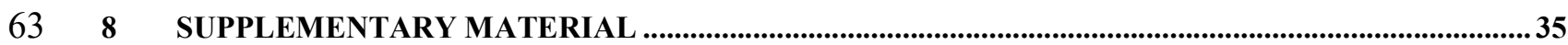

64

65 


\section{Introduction}

67 Intensive studies have been dedicated to trace and ultra trace metals determination in petroleum

68 products in the recent years [1-4]. The need of the petroleum industry in this field is related to exploitation activities and exploration : contamination during oil production and refining (e.g. prevention of catalyst poisoning, corrosion and pollution control [5]), and geochemical characterization of source rocks and basins in order to identify geochemical biomarkers [6] in oiloil or oil-source rock correlation. The existence of metals in fossil fuels was firstly established by Alfred Treibs in the 1930s [7]. Trace metals are also incorporated into petroleum fractions as organometallic compounds (e.g. geoporphyrins) initially present in the crude oil [8] or added during the various processes of refining [9]. Their concentration are always ranged between $\mu \mathrm{g} / \mathrm{kg}$ and $\mathrm{mg} / \mathrm{kg}$ levels but low amount of certain metals can have drastic effects as a contaminant. The determination of a particular metal is mainly driven by their poisoning effect on catalysts during refining processes [10]. It is then important to better characterise their distribution in the petroleum fractions as this can improve oil refining strategies. Thus, several characterization of metal complexes in petroleum products exist and if we focus on heavy fractions and oils that are more and more used in the petrochemical industry, vanadium (V), nickel (Ni), and sulfur (S) present in these oils plays a critical role during oil-refining processes. These elements could lead to corrosion of the equipment, environmental pollution, and contamination of the final petroleum products. In order to treat them efficiently, information on the size and chemical form (speciation) of these elements are of major importance to choose the porosity of refining catalysts.

87 Many techniques have been used for the determination of metals in petroleum fractions including

88 X-rays fluoresence (XRF) [11,12] or microwave induce plasma atomic emission spectrometry 89 (MIP-AES) [13] or even laser induced breakdown spectroscopy (LIBS) analysis [14]. For total 90 trace determination, inductively coupled plasma (ICP) techniques are generally used $[3,4,15,16]$ 91 and allow sufficient detection limits for most of the cases in the petroleum industry and are also 92 conventionnaly hyphenated to separation techniques to reach speciation analyses [17,18]. The 93 inherent high sensitivity of ICP-MS detection together with isotopic ratio capabilities opens new 94 fields of applications in petrochemistry or geochemistry, but the introduction of organic 95 substances is not that easy as this technique was not initially designed for organic samples 96 analysis [4]. Specific configurations of sample introduction systems are required in order to 
minimize organic solvent load into the ICP plasma [19]. Moreover, specific polyatomic

98 interferences are disturbing the spectra due to the massive presence of carbon, oxygen and sulfur

99 within the plasma, originating from the petroleum cuts. For this reason, various approaches have

100 been adopted within the last years in order to minimize the presence of carbon within the plasma:

101 emulsification, decomposition of the sample matrix, but also laser ablation and analysis through

102 electrothermal vaporization. Most of these approaches were already reviewed in [3] and the

103 advantages and drawbacks of the introduction of organic/hydro-organic matrices in ICP was

104 deeply reviewed by [4,20].

105 The determination of light or interfered elements done in the specific case of direct injection of

106 the organic substances within the plasma torch of the ICP-MS was mainly done with the help of

107 high resolution ICP-HRMS [21,22], essentially when difficult isotopic interferences are present

108 [23,24]. Such an instrument is quite expensive and not available in most of the lab of the

109 petroleum industry for routine organic analyses. The recent commercialisation of an inductively

110 coupled plasma tandem mass spectrometry (ICP-MS/MS) by Agilent [25-28] and Thermo

111 Fischer Scientific [29], is specifically dedicated to solve polyatomic interferences in organic

112 solvents and attain lower detection limit. It will be then interesting for the petroleum industry to

113 investigate this instrument in order to have a specific idea of the capabilities of such system for

114 difficult elements (for example S, Si, Fe) and especially for heavy matrices. In 2017, a complete

115 review about ICP-MS/MS applications for total and speciation analyses was published [28].

116 However, to our knowledge, a very few number of papers [26,30] are reported in the literature

117 about the application of the ICP-MS/MS to organic products with direct injection, and the most

118 difficult solvent used was ethanol. Ethanol is anyway not a sufficient "good solvent" to solubilize

119 most of the petroleum fractions and harsher solvent (difficult to introduce in the plasma) like

120 xylene or even THF are commonly used to dissolve hydrocarbons. In order to avoid difficult

121 organic solvent introduction into the plasma, two recents papers reported acid digestion of

122 petroleum products followed by ICP-MS/MS for multi elements analysis at trace levels, allowing

123 external calibration by means of aqueous standards but this preparation step is time consuming

124 compared to direct injection [31,32].

125 Also for the speciation of heavy crude oils a few number of papers is existing in the literature.

126 One of the main approches proposed actually in the litterature is based on the use of gel 
127 permeation chromatography (GPC) coupled to ICP-HRMS [23,24] and very recently ICP128 MS/MS [33].

129 This work is based on the direct injection of hydrocarbons after solvent dilution within the 130 plasma torch of the ICP-MS in order to minimize the preparation steps, but also to support 131 organic solvent issued from separation techniques. This article will present the two approaches 132 for total direct determination of organic substances and speciation with GPC obtained with an 133 ICP-MS/MS compared to ICP-HRMS for various elements and matrices. The interferences due 134 to the presence of carbon, oxygen and sulfur within the plasma are solved with the use of a 135 collision/reaction chamber [18] or the use of high resolution ICP-MS [21,34]. Optimization 136 parameters for these two configurations are optimized and the different figures of merit are 137 discussed concerning linearity, background equivalent concentration (BEC) and detection limits. 138 Three cases of application in the petroleum industry (Ultra trace sulfur in solvents, Asphaltene 139 elemental composition and Speciation in heavy matrices) are then presented to give an overview 140 of the capabilities of the ICP-MS/MS compared to the ICP-HRMS. 


\section{Materials and methods}

\section{$143 \quad 2.1$ Solutions and samples}

144 Different lots of the same solvent grades of toluene and xylene (mixture of o, m, p-xylene) 145 AnalaR Normapur were obtained from VWR Chemicals (Fontenay s/s Bois, France) and used for 146 most of the preparation and sulfur detection. For the GPC experiments, American Chemical 147 Society-grade THF with $250 \mathrm{ppm}$ of butylated hydroxytoluene (BHT) as stabilizer (Scharlau, 148 Spain) was used for the solutions, sample dilutions and as the mobile phase. A Premisolv solvent 149 was provided by SCP Science (Courtaboeuf, France) and used as a sulfur free solvent.

150 A Conostan (SCP Science, Courtabouef, France) multi-element oil-based standards (S-21+CoK) 151 containing $500 \mathrm{mg} / \mathrm{kg}$ of $\mathrm{Ag}, \mathrm{Al}, \mathrm{B}, \mathrm{Ba}, \mathrm{Ca}, \mathrm{Cd}, \mathrm{Co}, \mathrm{Cr}, \mathrm{Cu}, \mathrm{Fe}, \mathrm{K}, \mathrm{Mg}, \mathrm{Mn}, \mathrm{Mo}, \mathrm{Na}, \mathrm{Ni}, \mathrm{P}, \mathrm{Pb}$, $152 \mathrm{Si}, \mathrm{Sn}, \mathrm{Ti}, \mathrm{V}$ and $\mathrm{Zn}$ was used. A specific mono-elemental oil-based standard was used for $\mathrm{S}, \mathrm{Hg}$ 153 and As calibration. Multi-element working standard solutions at 0.10, 0.20, 0.50, 1.0, 2.0, 5.0, 10, 15420 and $50 \mu \mathrm{g} / \mathrm{kg}$, were prepared by the appropriate dilution of these solutions in xylene. 155 Calibration solutions were prepared by weighing and the exact added concentrations were 156 recalculated afterwards.

157 Different petroleum cuts are provided by IFP Energies nouvelles (IFPEN) (Solaize, France) and 158 their main characteristics are described in Table 1. Straight Run Naphtha samples directly issued 159 from different refineries were used as sulfur free solvent. Vacuum residue (VR) from Middle East 160 already used in [24] and its hydrotreated (HDT) vacuum residue issued from a deep 161 hydrodemetallation pilot plant experiment (E) were used for GPC analyses. Asphaltenes fraction 162 (A) was recovered from the partial Vacuum residue flocculation in contact with the n-heptane as 163 already described in [35]. 
Table 1: Characteristics of the petroleum cuts provided for the various experiments.

\begin{tabular}{|l|l|l|l|l|l|l|}
\hline Samples & \multicolumn{6}{l}{$\begin{array}{l}\text { Simulated distillation } \\
\text { IFPEN } 1202\end{array}$} \\
\cline { 2 - 8 } & T5 & T50 & T95 & Ni $[\mathrm{mg} / \mathrm{kg}]$ & V $[\mathrm{mg} / \mathrm{kg}]$ & S [\%w/w] \\
\hline Asphaltene A & na & na & na & 350 & 655 & na \\
\hline Naphtha 16J & 15 & 88.7 & 158 & na & na & na \\
\hline Naphtha 16F & 49 & 100 & 185 & na & na & na \\
\hline Naphtha 16A & 24 & 71 & 145 & na & na & na \\
\hline Vacuum Residue VR & 482 & 625 & 725 & 58 & 183 & 5.7 \\
\hline HDT vacuum residue E & na & na & na & 3 & 6 & 0.49 \\
\hline
\end{tabular}

na: not available

\subsection{Instrumentation}

174 ICP-MS and GPC-ICP-MS analyses were achieved using an ICP-MS/MS and a ICP-HRMS. The most important instrumental parameters are presented in Table 2. The first one is an ICP-MS/MS 8800 instrument from Agilent (Agilent Technologies, Japan). In this instrument, the collisionreaction cell $(\mathrm{CRC})$ is an octopole located in-between two quadrupole analyzers, this cell can be

178 filled with a collision or a reactive gas in order to reduce interferences on the ions of interest. All 179 monitored isotopes are detailed in Table 2 in function of the resolution (low, medium, high) for 180 the ICP-HRMS and gas mode (no gas, $\mathrm{He}, \mathrm{H}_{2}$ and $\mathrm{O}_{2}$ mode) for the ICP-MS/MS. In No gas 181 mode, the width of the bandpass of the first quadrupole analyzer is fully open or used as an ion 182 guide and the second quadrupole analyzer is set at the chosen mass. In He gas mode, the width of 183 the bandpass of the first quadrupole analyzer is fully open and the second quadrupole analyzer is 184 set at the chosen mass. In $\mathrm{H}_{2}$ gas mode, the width of the bandpass of the first quadrupole analyzer 185 is set to single mass width and the second quadrupole analyzer is set to the same single mass 186 width because $\mathrm{H}_{2}$ did not react with the chosen elements. Finally for the $\mathrm{O}_{2}$ gas mode, the width 187 of the bandpass of the first quadrupole analyzer is set to the element of interest mass width and 188 the second quadrupole analyzer is set to the element of interest mass width +16 to let the 189 monoxide of the element going through the second quadrupole: For some elements in the oxygen 
190 mode, the mass of the second quadrupole is let to the same single mass width in order to verify

191 the reactivity of the element and how much has not reacted within the collision/reaction chamber.

192 This was the case for ${ }^{48 \rightarrow 48} \mathrm{Ti},{ }^{51 \rightarrow 51} \mathrm{~V},{ }^{56 \rightarrow 56} \mathrm{Fe},{ }^{59 \rightarrow 59} \mathrm{Co},{ }^{60 \rightarrow 60} \mathrm{Ni},{ }^{62 \rightarrow 62} \mathrm{Ni},{ }^{75 \rightarrow 75} \mathrm{As}$.

193 The second ICP-MS is an Element XR double focusing sector field inductively coupled plasma 194 mass spectrometer (Thermo Fisher, Germany). A micro-flow total consumption nebulizer (DS-1, 195 Cetac) without drain [36] was tested. Samples were delivered using an ASX-520 (CETAC, 196 Omaha, NE) autosampler. Some elements were monitored with low resolution $(\mathrm{R}=300)$, medium 197 resolution $(\mathrm{R}=4000)$ and high resolution mode $(\mathrm{R}=10000)$. Samples were delivered using an 198 ASX-500 (CETAC, Omaha, NE). For total experiments, the reduction of the amount of organic 199 vapor entering the plasma was obtained using a Peltier-cooled spray chamber cooled down at -5 $200{ }^{\circ} \mathrm{C}$.

201 For both instruments, the sampler and skimmer cones covered with Pt were used due to organic 202 injection and the necessity of adding oxygen within the plasma.

203 For the GPC experiment, the mobile phase was delivered by a Dionex HPLC system with an 204 UltiMate 3000 microflow pump, an UltiMate 3000 autosampler, and a low port-to-port dead205 volume microinjection valve. Chromatographic separation was performed by three polystyrene206 divinylbenzene GPC columns connected in series (porosity of $100 \AA, 1000 \AA$ and 10,000 $\AA$ ). The 207 GPC eluted fractions were splited to introduce the same flow of $0.03 \mathrm{ml} / \mathrm{min}$ as total analysis 208 (Table 2) into the high resolution ICP-MS via a modified DS-5 microflow total consumption 209 nebulizer (CETAC, Omaha, NE) fitted with a laboratory-made single-pass glass spray chamber 210 thermostated at $60{ }^{\circ} \mathrm{C}$ by a water/glycol mixture using a temperature controlled bath circulator 211 (Neslab RTE-111, Thermo Fisher Scientific, Waltham, MA).

212 The same set of columns was used with the Agilent 8800 ICP-MS instrument. An Agilent 1290 213 Infinity liquid chromatographic device was used. The elution system was equipped by specific 214 THF resistant parts. In this case, the total GPC eluted fractions was introduced within the Scott 215 spray chamber by the means of a Burgener T2002 nebulizer using Pharmed tubing.

216 To minimize carbon-buildup on the sampler cone, $\mathrm{O}_{2}$ was added within a mixture of 217 Argon/oxygen $\left(\mathrm{Ar} / \mathrm{O}_{2}: 80 / 20\right)$ between the spray chamber and the torch for the ICP-MS/MS, a 218 typical flow between 230 and $270 \mathrm{~mL} / \mathrm{min}$ of the $\mathrm{Ar} / \mathrm{O}_{2}$ mixture is used depending on the 219 application. Pure oxygen was added to the sample Ar flow using a mass flow controller with the 220 ICP-HRMS, a flow of $80 \mathrm{~mL} / \mathrm{min}$ was used. 
Table 2: Operating conditions for total analysis using ICP-MS apparatus

\begin{tabular}{|c|c|c|}
\hline & $\begin{array}{l}\text { Thermofisher Element HRMS with } \\
\text { DS-1 }\end{array}$ & Agilent ICP-MS/MS 8800 \\
\hline RF power [W] & 1500 & 1550 \\
\hline Plasma gas flow [L/min] & 16 & 18 \\
\hline Optional gas flow [L/min] & $\mathrm{O}_{2}: 0.08$ & $\mathrm{Ar}+\mathrm{O}_{2}: 0.23-0.27^{*}$ \\
\hline Carrier gas flow [L/min] & 0.565 & 0.50 \\
\hline Auxiliary gas flow rate [L/min] & 0.9 & \\
\hline Number of replicates & 3 & 3 \\
\hline Liquid flow rate $[\mathrm{ml} / \mathrm{min}]$ & 0.03 & $0.50-0.70^{*}$ \\
\hline Nebulizer & Modified DS-5 & Burgener T2002 \\
\hline Nebulization chamber & $\begin{array}{l}\text { Low dead volume }\left(8 \mathrm{~cm}^{3}\right) \text { spray } \\
\text { chamber without drain }[36]\end{array}$ & Scott type - double pass \\
\hline Spray chamber temperature $\left[{ }^{\circ} \mathrm{C}\right]$ & 60 & -5 \\
\hline Torch Z-position [mm] & -3 & 5 \\
\hline Injector & $1.0 \mathrm{~mm}$ ID quartz injector & 1.0 or $1.5 \mathrm{~mm}$ ID quartz injector \\
\hline Detection mode & Triple & \\
\hline $\begin{array}{llr}\text { Resolution (HRMS) and } & \text { gas } \\
\text { mode (ICP-MS/MS) } & \text { for } \\
\text { monitored elements } & \end{array}$ & 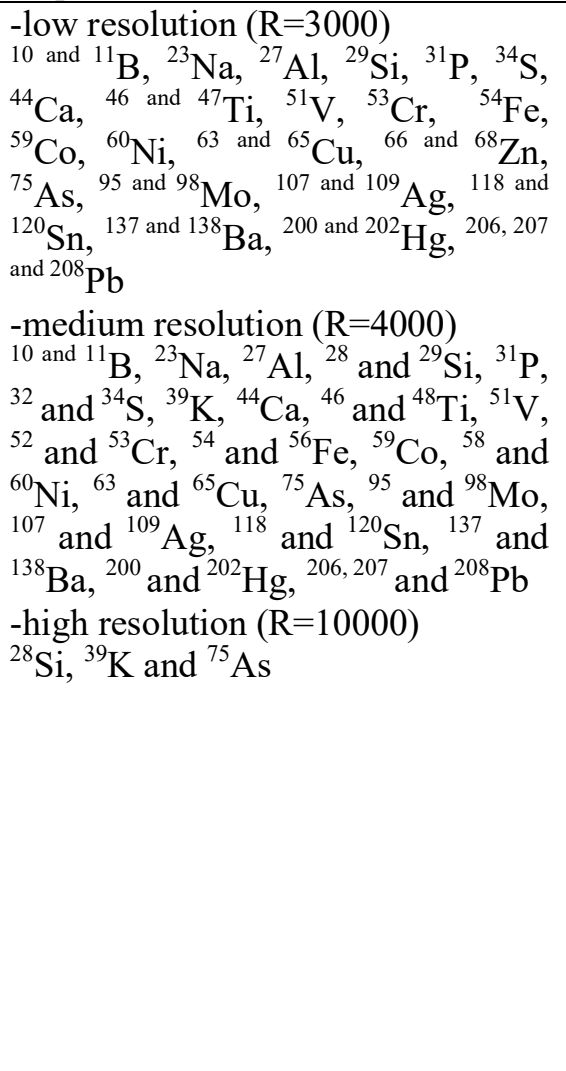 & 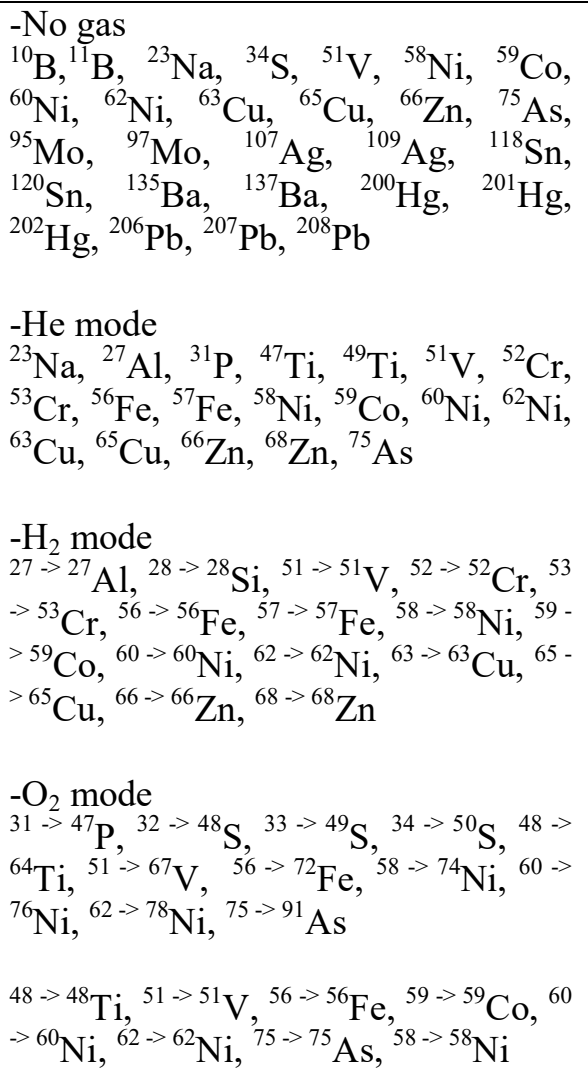 \\
\hline Extract [V] & -2000 & $1: 0-2:-160$ \\
\hline Omega bias [V] & & -80 \\
\hline Cell gas & & $\begin{array}{l}\text { no gas } / \mathrm{O}_{2}(0.23-0.32 \mathrm{~mL} / \mathrm{min}) / \mathrm{He} \\
(2-3 \mathrm{~mL} / \mathrm{min}) / \mathrm{H}_{2}(2-3.1 \mathrm{~mL} / \mathrm{min})\end{array}$ \\
\hline
\end{tabular}

*For GPC, different liquid and $\mathrm{Ar}+\mathrm{O}_{2}$ flow rates are used after optimization 
224 UVF analysis following ISO 20486 was performed using an Antek Multitek (PAC-Alytech, 225 Juvisy sur Orge, France) with syringe injection. The instrument was calibrated between 0.2 and 2 $226 \mathrm{mg} / \mathrm{kg}$ with DiButylSulfide and a volume of $20 \mu \mathrm{L}$ was injected.

227 For wavelength dispersive X-rays fluorescence (WDXRF) analysis, a Panalytical Axios (Almelo, 228 Netherlands ) $4 \mathrm{~kW}$ equipped with a $\mathrm{Cr}$ anode was used. $6 \mathrm{ml}$ of the solution was introduced 229 within a cup with a Mylar $6 \mu \mathrm{m}$ film. The $\mathrm{Ni}$ and $\mathrm{V} \mathrm{K}_{\alpha}$ were followed and the $\mathrm{C} / \mathrm{H}$ and $\mathrm{S}$ matrix 230 effect were compensated using the Cr Compton line according to an internal IFPEN method. 


\section{Results and discussion}

\section{$233 \quad 3.1$ Optimization of the ICP operating parameters}

234 The configuration of the ICP-MS/MS and the ICP-HRMS was tested by calibrating the

235 instruments between 0 to 50 or $100 \mu \mathrm{g} / \mathrm{kg}$ in xylene. Polyatomic interferences were solved by the

236 use of medium resolution $(\mathrm{R}=4000)$ with the HRMS or with the use of the a collision/reaction

237 cell using the ICP-MS/MS. For the different gas modes used with the ICP-MS/MS, the carrier

238 gas was firstly optimized and then the various lenses were adjusted. The gas flow in the

239 collision/reaction was finally optimized according to each application tested in order to reach the

240 best signal to noise ratio.

241 Most of the optimized parameters both for the ICP-MS/MS and the ICP-HRMS are reported in

242 Table 2. According to Agilent recommendations for organic introduction, the standard injector

243 tube (2.5 $\mathrm{mm}$ internal diameter) was replaced by a $1.5 \mathrm{~mm}$ i.d. injector. Two types of injector

244 were tested with the 1.5 and $1.0 \mathrm{~mm}$ internal diameter. The two configurations tested shows that

245 for most of the elements the $1.0 \mathrm{~mm}$ injector allowed similar detection limit or increase of the

246 sensitivity by a factor up to 10 times. This increase of sensitivity was more effective for lighter

247 elements with atomic mass lower than 30 (Figure 1). The $1.0 \mathrm{~mm}$ injector was then kept for each

248 application, as previously reported by Poirier et al., [15] for the total analysis of $\mathrm{Ni}, \mathrm{V}, \mathrm{Fe}$ and $\mathrm{Ca}$

249 in petroleum crude oil via direct dilution using ICP-MS. 


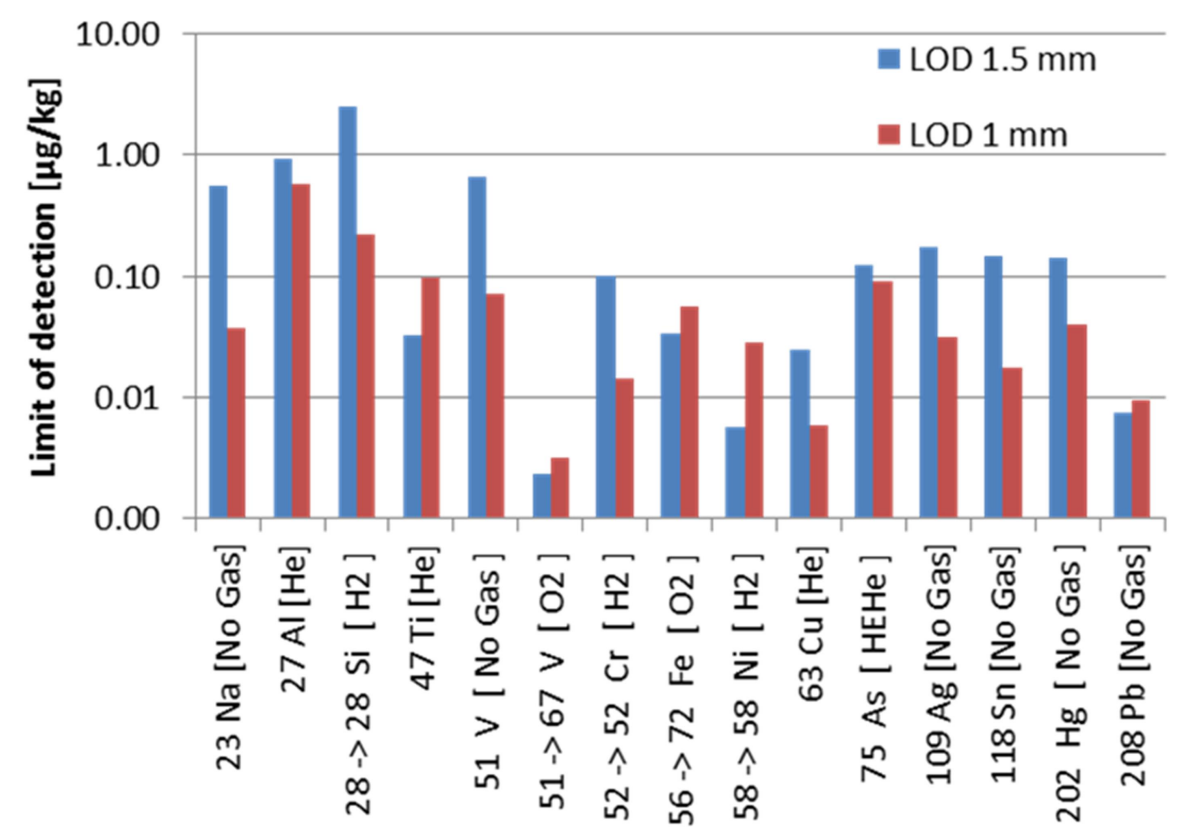

Figure 1: Comparison of detection limits obtained using diameters 1.0 and $1.5 \mathrm{~mm}$ for two injectors proposed for the ICP-MS/MS.

\subsection{Analytical figures of merit}

256 For each element, the calibration curve was built acquiring the signal for various isotopes and using the diversity of the modes offered by each instrument. Low, medium and high resolutions were followed with the ICP-HRMS and the no gas, helium, hydrogen and oxygen modes were used and optimized with the ICP-MS/MS. Typical curves for heavy interfered elements (S, Si,

$260 \mathrm{Fe}$ ) are respectively shown Figure 2 to Figure 4 for the most sensible mode retained for each 261 element. From each calibration curve, the limit of detection (LOD) and the background 262 equivalent concentration (BEC) are calculated according to the following equation:

$264 y=a x+b$ with $B E C=b / a$ and $L O D=3 x B E C x R S D_{b l k}[37]$

265 The relative standard deviation of the blank $\left(R S D_{b l k}\right)$ was calculated according to 3 replicates of 266 xylene. 


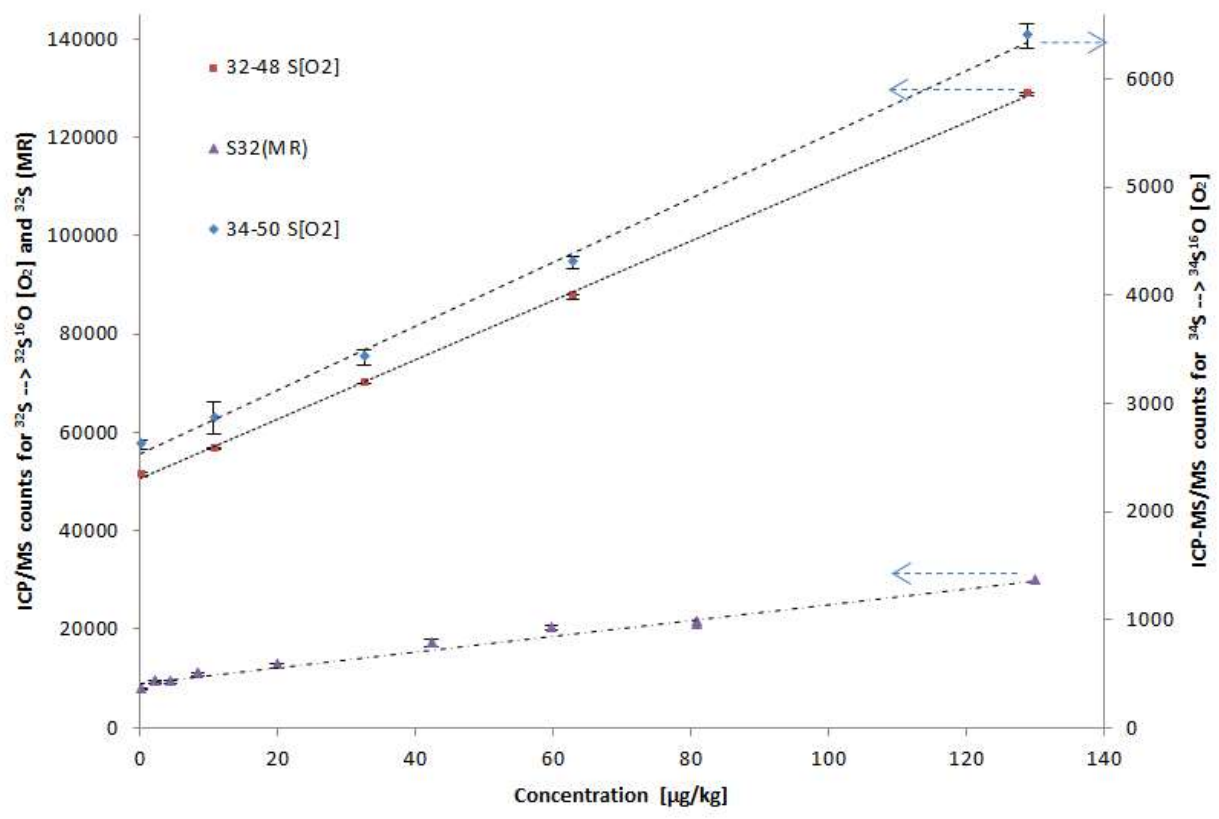

269 Figure 2: Calibration curves for S using ICP-HRMS or ICP-MS/MS (Arrows indicate the correct 270 axis for all calibration curves)

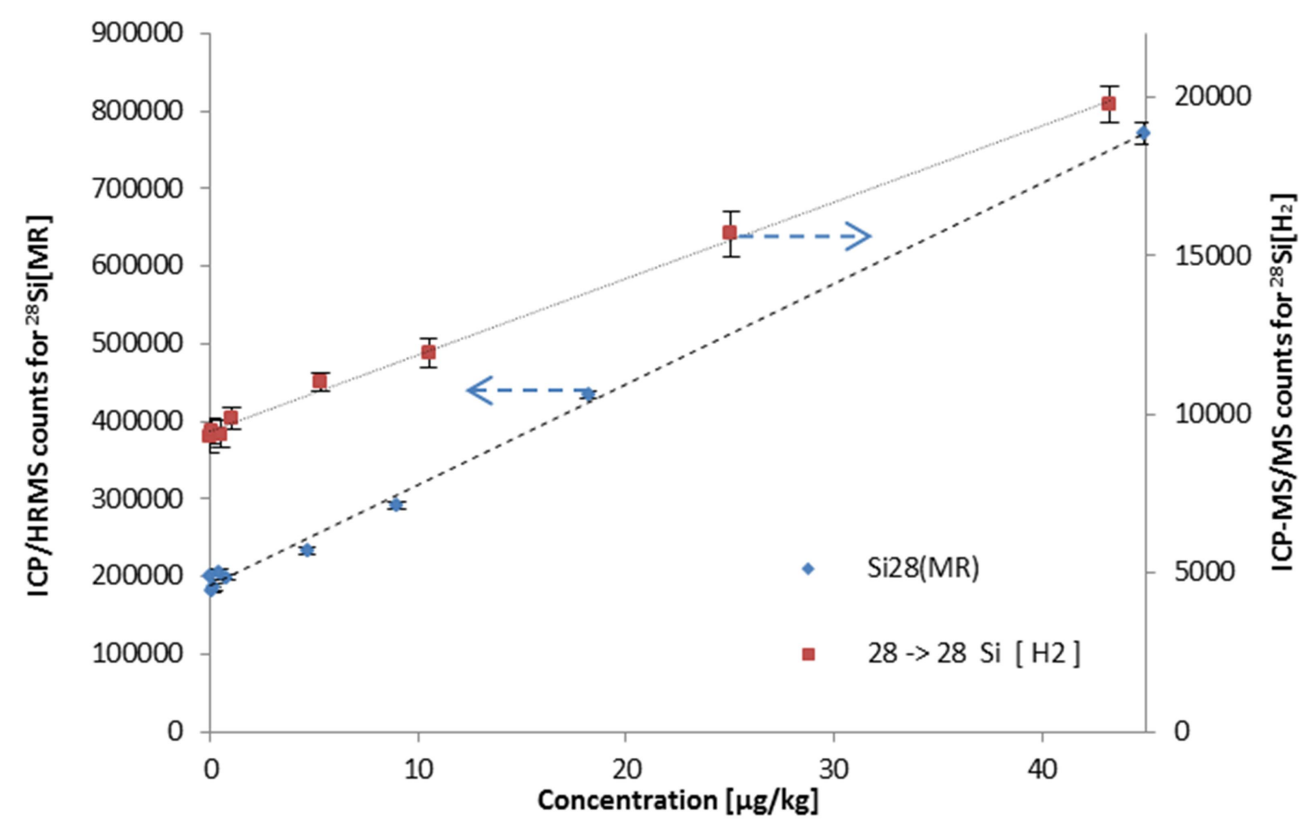




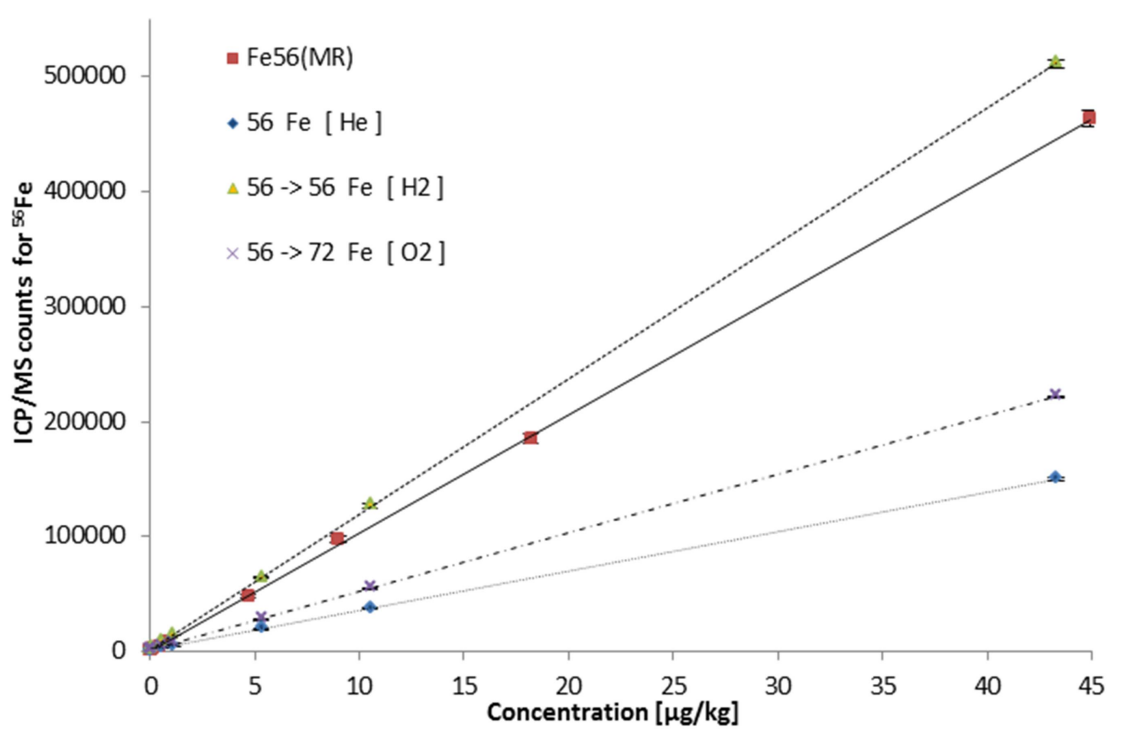

281 For S, Si, and Fe, respectively presented in Figure 2, Figure 3 and Figure 4, a nice sensitivity is 282 obtained allowing trace elemental analysis in organic products. Anyhow, the BEC for S and Si is 283 rather high compared to Fe. This high BEC might be due to contamination of the solvent or 284 background emission not resolved by the high resolution or configuration of the ICP-MS/MS. For $285 \mathrm{~S}$, the origin of this BEC will be discussed later in 3.3.1, but for Si this phenomenon was already observed in Chainet et al. [18] and was attributed to the use of an injector and torch made of quartz that provoke a Si background signal.

288 The results obtained for most of the elements for both the ICP-HRMS and the ICP-MS/MS are 289 represented in Figure 5. For light elements $(Z<40)$ having no specific interferences, the new ICP$290 \mathrm{MS} / \mathrm{MS}$ has better or similar performances than the ICP-HRMS. For heavy elements $(\mathrm{Z}>70)$, the 291 ICP-MS/MS is a little bit less sensible than the ICP-HRMS due to a better transmission of ions 292 through the magnetic and electrostatic sectors in the low resolution mode. This is also due to the 293 fact that these elements do not suffer from interferences and that the low-resolution mode is 
294 sufficient to transmit these isotopes to the detector. For more difficult elements having 295 interferences, the potential of the ICP-MS/MS with different gases $\left(\mathrm{H}_{2}, \mathrm{He}, \mathrm{O}_{2}\right)$ and the use of the 296 initial quad to limit the analyte entering the reaction chamber allows similar or better 297 performances than the ICP-HRMS using medium resolution. Important elements for the 298 petroleum industry ( $\mathrm{S}, \mathrm{Si}, \mathrm{Fe}$ ), but also for new biofuels specifications ( $\mathrm{P}, \mathrm{Ca}$ ) have excellent 299 performances compared to conventional system using traditional single quadrupole ICP-MS. 300 301 

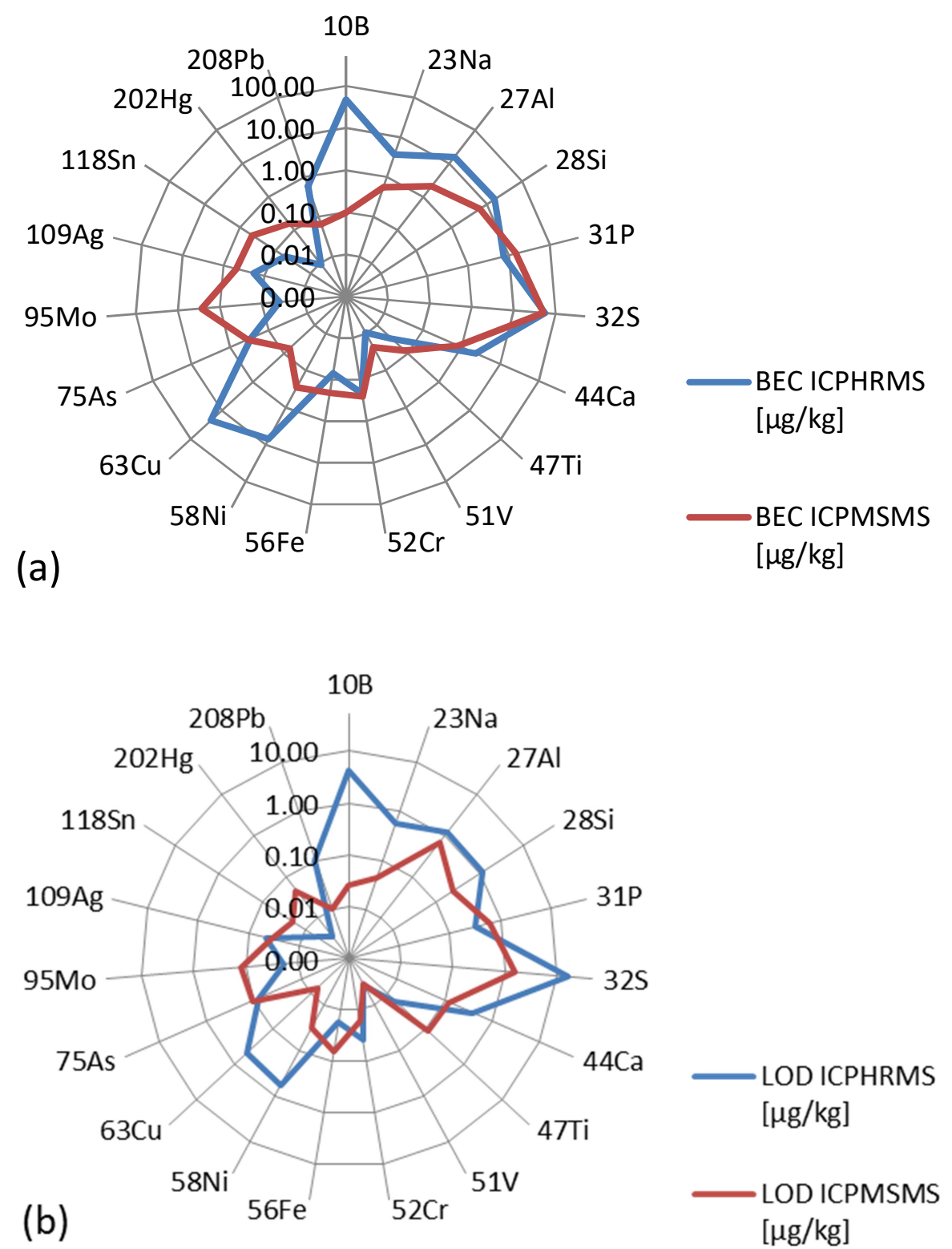

Figure 5: Comparison of Background Equivalent Concentration (a) and Limit of Detection (b) for 306 various elements between ICP-HRMS and ICP-MS/MS detection. 


\subsubsection{Ultra trace sulfur determination in solvents using ICP-MS/MS}

310 The sulfur determination in petroleum products is not a real challenge as most of products are 311 containing more than traces level of sulfur. There is however some cases where the sulfur 312 concentration might be challenging, typically for naphtha used in reforming application where the 313 concentration of sulfur might be as low as possible. When the calibration for sulfur is done at low 314 level (Figure 2), the BEC is important compared to the LOD obtained for such element (Figure 5) 315 and this was already pointed by preceding work [26]. Anyhow, most of the work done until now 316 for $\mathrm{S}$ in organic matrices with ICP-MS/MS are using isotopic dilution after digestion procedure $317 \quad[27,30-32]$ and measure $\mathrm{S}$ levels between $4 \mathrm{mg} / \mathrm{kg}$ and $2.7 \%$.

318 For very low levels of $\mathrm{S}$, it was then important to determine the origin of this BEC, considering 319 that different sources of BEC can be attributed. Typically, the BEC can be due to solvent 320 contamination $\left(\mathrm{BEC}_{\text {solvent }}\right)$ or noise due to the instrumentation contamination or electronic noise 321 of the detection. $\left(\mathrm{BEC}_{\text {instrumental }}\right)$. It should be noted that using digestion procedures, Yang et al. 322 [32] observe a very low BEC in aqueous matrices.

323 Four different solvents (toluene, xylene, naphtha, Premisolv) were then tested to determine the 324 various contributions of the BEC with different lot numbers and volatility. For this experiment, a 325 calibration curve was prepared with adding of S using a sulfur mono-elemental oil-based standard 326 between 5 and $300 \mu \mathrm{g} / \mathrm{kg}$ in the four selected solvents. These mixtures were introduced into the 327 ICP-MS/MS and the settings of the plasma were adjusted in order to have the best signal to noise 328 ratio of the instrument depending on the volatility of the solvent injected. One condition per 329 solvent were retained and the ${ }^{32->}{ }^{48} \mathrm{~S}$ and ${ }^{34->50} \mathrm{~S}$ transition were kept to measure the $\mathrm{S}$ signal 330 within each solvent. The ${ }^{34} \mathrm{~S} /{ }^{32} \mathrm{~S}$ isotope ratio of the $\mathrm{S}$ signal within the different solvents is 331 interesting with a value of $21.20 \pm 0.83$. This value is very similar to the theoretical value of 22.5

332 for the relative abundance of naturally $\mathrm{S}$ occurring isotope and this concordance might confirm 333 that the BEC of the instrument is mainly driven by the $\mathrm{S}$ signal and not due to electronic noise.

334 The BEC obtained for each solvent and conditions is given in Table 3. The BEC is not equivalent 335 when different lots of the same solvent are analyzed. As the conditions of the plasma was linked 336 to the use of specific solvent and different BEC were obtained with an unique condition of the 337 plasma, this difference of the BEC can then be attributed to the lot number of the solvent and then 
338 directly to its residual S concentration. This indicates that the residual S concentration present in 339 the solvent might be the only contributor to the $\mathrm{BEC}$ and that the $\mathrm{BEC}_{\text {instrumental }}$ might be 340 negligible. The Premisolv was also analyzed by UVF following ISO 20846 due to its high level 341 of sulfur. A comparative value of $233 \mu \mathrm{g} / \mathrm{kg}$ was obtained with this technique, showing that the 342 level of the BEC with the ICP-MS/MS $(251 \mu \mathrm{g} / \mathrm{kg})$ is mainly due to the S contamination. The 343 BEC obtained for each new solvent can then be assigned to the level of concentration of sulfur in 344 the solvent as it is conventionally done when standard addition are used. It is then possible to 345 measure ppb level of $\mathrm{S}$ in various solvents by spiking the solvent with increasing concentrations 346 of $\mathrm{S}$ and determining the $\mathrm{S}$ content by standard addition. It is interesting to note that pollution 347 between 30 to $250 \mu \mathrm{g} / \mathrm{kg}$ of S were observed in the various solvents used in this work. Such 348 information might be crucial for selecting feed used in reforming application.

349 Table 3: BEC [ $\mu \mathrm{g} / \mathrm{kg}]$ of ${ }^{32 \rightarrow 48} \mathrm{~S}$ obtained for each solvent and plasma conditions.

\begin{tabular}{|l|l|l|l|l|}
\hline $\begin{array}{c}\text { Lot number } \\
\text { Solvents: }\end{array}$ & Naphtha & Toluene & Xylene & Premisolv \\
\hline $16 \mathrm{~J}$ & 75 & & 78 & \\
\hline $16 \mathrm{~F}$ & 86 & 80 & 32 & \\
\hline $15 \mathrm{G}$ & & & 54 & \\
\hline $16 \mathrm{~A}$ & 68 & 98 & & \\
\hline others & & & & 251 \\
\hline
\end{tabular}

\subsubsection{Trace elemental composition of Asphaltenes by ICP-MS/MS}

351 Asphaltenes fraction are known to contain an important concentration of $\mathrm{Ni}, \mathrm{V}$ and $\mathrm{S}$ that are 352 easily measured due to their high level, but the minor traces are barely investigated and it might 353 be interesting to evaluate if others metals are present in the asphaltenes fractions of some crude 354 oil. In order to evaluate the feasibility of such determination, a multi-element oil-based standard 355 (S-21+CoK) was used to calibrate the instrument in THF between 0 to $100 \mu \mathrm{g} / \mathrm{kg}$. The conditions 356 of nebulization and each mode of gas $\left(\mathrm{H}_{2}, \mathrm{He}\right.$ and $\left.\mathrm{O}_{2}\right)$ were optimized due to the fact that the 357 volatility of THF is different than xylene previously used in section 2.2.1. Higher flow of oxygen 358 (0.27 compared to $0.20 \mathrm{~mL} / \mathrm{min})$, hydrogen (3.1 compared to $2.0 \mathrm{~mL} / \mathrm{min}$ ) and $\mathrm{He}$ ( $3.5 \mathrm{compared}$ 359 to $2.5 \mathrm{~mL} / \mathrm{min}$ ) was observed for the optimum signals in the gas cell, as it was the case for the 
360 optional gas $(0.31$ compared to $0.20 \mathrm{~L} / \mathrm{min})$. The asphaltenes fraction was diluted between 700 to 36185000 times in THF and measured subsequently. Yttrium was added to all solutions to verify the 362 potential impact of the viscosity of the solution and controlling the efficiency of the nebulizer 363 with the asphaltene solution. The sulfur concentration was not measured due to the presence of 364 sulfonates in the initial multi-element standard solution, but also the high concentration of such 365 element that is not needing trace analysis instrument. The same fraction of asphaltene was diluted 366 in toluene and measured by WDXRF using an internal method to measure $\mathrm{S}$, Ni and $\mathrm{V}$ 367 concentrations of the prepared solution. The results obtained for many elements are given in 368 Table 4. Concentrations obtained for Ni $(380 \mathrm{mg} / \mathrm{kg})$ and V $(630 \mathrm{mg} / \mathrm{kg})$ by ICP-MS/MS are 369 quite comparable to the conventional WDXRF IFPEN method (322 mg/kg for Ni and $655 \mathrm{mg} / \mathrm{kg}$ 370 for $\mathrm{V}$ ) and allow to validate the analysis of the asphaltene. As already described in the literature 371 [38], iron is the fourth element present in the asphaltene fraction in terms of concentration. The 372 value obtained for Mo is also very similar to others values available in the literature [16,39]. The 373 others elements are in the same order of magnitude with value observed in the literature between 374 sub ppm level to tenth of ppm [16,39]. Amongst them, the value for tin is quite high and might be 375 due to container contamination. 


\begin{tabular}{|l|l|l|}
\hline \multirow{2}{*}{ Elements } & \multicolumn{2}{|l|}{ Concentration $[\mathrm{mg} / \mathrm{kg}]$} \\
\cline { 2 - 3 } & WDXRF & ICP-MS/MS \\
\hline $\mathrm{V}$ & 655 & 630 \\
\hline $\mathrm{Ni}$ & 322 & 380 \\
\hline $\mathrm{S}(\%)$ & 6.87 & $\mathrm{~nm}$ \\
\hline $\mathrm{Fe}$ & $\mathrm{nm}$ & 37.4 \\
\hline $\mathrm{Sn}$ & $\mathrm{nm}$ & 25 \\
\hline $\mathrm{Mo}$ & $\mathrm{nm}$ & 8.8 \\
\hline $\mathrm{Zn}$ & $\mathrm{nm}$ & 6.4 \\
\hline $\mathrm{K}$ & $\mathrm{nm}$ & 4.2 \\
\hline $\mathrm{Si}$ & $\mathrm{nm}$ & 3.9 \\
\hline $\mathrm{Cr}$ & $\mathrm{nm}$ & 3.3 \\
\hline $\mathrm{Ag}$ & $\mathrm{nm}$ & 1.7 \\
\hline $\mathrm{Co}$ & $\mathrm{nm}$ & 1.6 \\
\hline $\mathrm{Ba}$ & $\mathrm{nm}$ & 1.3 \\
\hline $\mathrm{Cu}$ & $\mathrm{nm}$ & 1.2 \\
\hline $\mathrm{Ti}$ & $\mathrm{nm}$ & 0.8 \\
\hline $\mathrm{Pb}$ & $\mathrm{nm}$ & 0.3 \\
\hline $\mathrm{Al}$ & $\mathrm{nm}$ & 0.3 \\
\hline
\end{tabular}

nm : not measured

3.3.3 Speciation of $N i, V$ and $S$ in heavy petroleum cuts by GPC-ICP-MS

393 Based on the excellent performance of the ICP-MS/MS for the sensitivity obtained for the 394 calibration curve (Section 3.2), it was then interesting to investigate the response of the 395 instrument when it was coupled to liquid chromatography and more specifically to GPC. Such 396 technique is used since years to investigate the size of $\mathrm{Ni}, \mathrm{V}$ and $\mathrm{S}$ in various petroleum cuts, but 397 all of these publications are based on the use of GPC coupled to ICP-HRMS [23,24]. The 398 challenge to follow transient signal is the need of numerous points per peak in order to avoid loss 399 of resolution in the chromatogram. A very recent article mentioned the use of ICP-MS/MS to 
400 monitor elemental signature on liquid chromatography [33]. Previous assay done in this work 401 (section 3.1) have shown that different gas modes might be necessary to have the best sensitivity 402 and previous work done with the ICP-HRMS have shown the use of different resolution 403 according to the measured element. Switching between two gas mode require 10 seconds at least 404 with the ICP-MS/MS and such switch is not feasible when the instrument is coupled to a 405 separation technique. The change of mode between high and medium resolution for ICP-HRMS 406 is also not described in the literature but require at least few seconds of stabilization. 407 Consequently, it is not compatible with the monitoring of chromatograms. It was then important 408 to investigate which mode of gas was the most adequate to monitor $\mathrm{Ni}, \mathrm{V}$ and $\mathrm{S}$ during the same 409 acquisition. For the ICP-HRMS, previous work have shown that $\mathrm{S}$ is detected using medium 410 resolution only in order to solve the interference on the mass 32. Such higher resolution is also 411 reducing the intensity of the final signal due to a lower slit in front of the magnetic sector and 412 might be a limitation for trace element analysis. This is illustrated by the 10 times difference of 413 signal for Ni between low and medium resolution in Figure 6. Then for low concentration $(<5$ $414 \mathrm{mg} / \mathrm{kg} \mathrm{Ni} \mathrm{ital}_{\text {tol }}$ ), two injections are necessary in order to acquire $\mathrm{V}$ and $\mathrm{S}$ with the medium 415 resolution and $\mathrm{Ni}$ and $\mathrm{V}$ with low resolution. Such choice has an important impact on the sample 416 throughput due to the time of the analysis (120 minutes of run for GPC [24]).

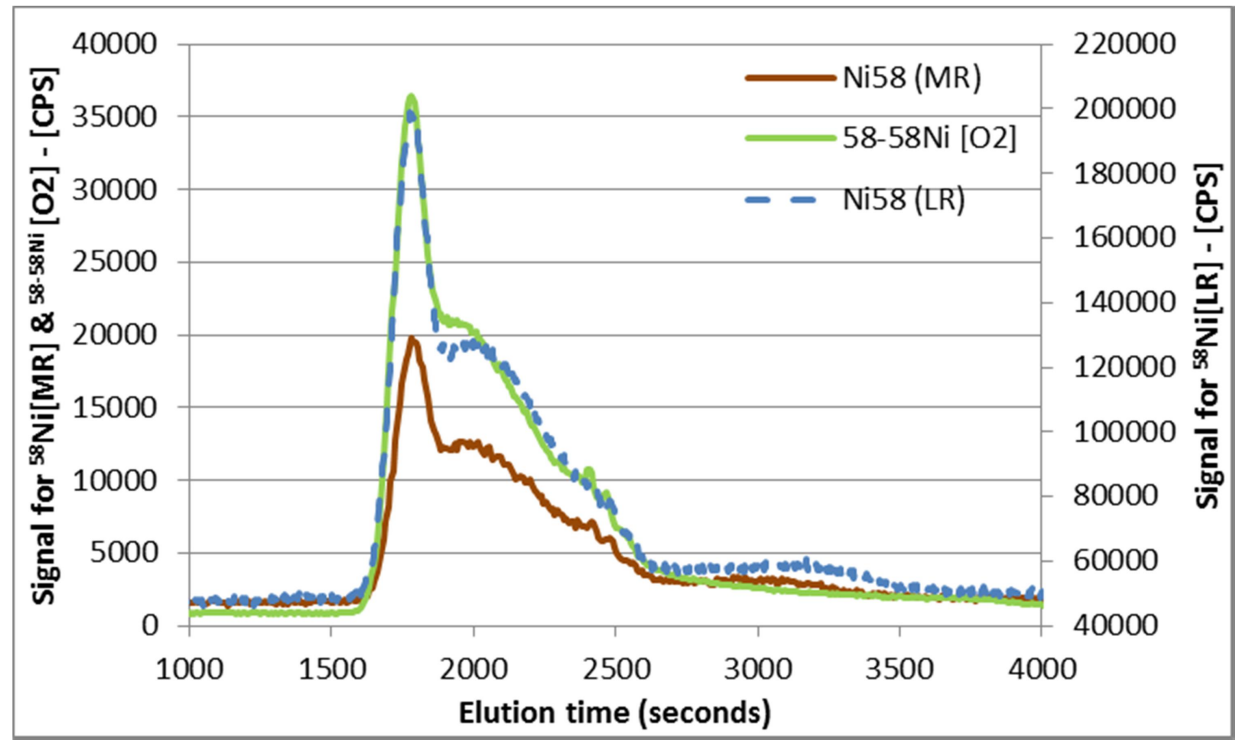

418 Figure 6: Comparison of GPC-ICP-MS/MS and GPC-ICP-HRMS chromatograms for Ni, injecting 419 a VR with Ni content around $60 \mathrm{mg} / \mathrm{kg}$ 
421 For the ICP-MS/MS, the $\mathrm{O}_{2}$ mode was quite efficient for $\mathrm{S}$ (Figure 2) and V (Figure 1 and Figure

$422 \mathrm{~S} \mathrm{1}$ ), but less effective for $\mathrm{Ni}$ due to the high enthalpy of reaction of Ni with oxygen. The He or $423 \mathrm{H}_{2}$ mode was quite sensitive and was initially retained in the total injection (Figure 1) leading to 424 lower sample throughput as in the case of ICP-HRMS for low concentration. Another way to 425 observe an element with the ICP-MS/MS is to provoke a reaction within the reaction/collision 426 cell and selecting the isotope that has not reacted at the end of the chamber. This is an interesting 427 way to understand what has happened between the two quadrupole and is useful to understand 428 and optimize the various instrumental conditions. Interestingly, the amount of Ni going through 429 the reaction/collision chamber without reacting with oxygen was quite important and sufficient 430 signal was obtained by looking at the ${ }^{58 \rightarrow 58} \mathrm{Ni}\left[\mathrm{O}_{2}\right]$ mode.

431 A vacuum residue (VR) and its hydrotreated fraction (E) were eluted on the GPC column and the 432 chromatogram obtained with the different modes are presented Figure 7 and Figure 8 . The use of $433 \mathrm{O}_{2}(2.5 \mathrm{~mL} / \mathrm{min})$ with $\mathrm{Ni}, \mathrm{V}, \mathrm{S}$ is particularly interesting for transient signal and allow the 434 monitoring of the 3 elements in one mode only for the vacuum residue. For S and V (Figure 7), 435 the signal is pretty similar for both instrument using the oxygen mode and the medium resolution 436 but the signal to background ratio is slightly $(+10 \%)$ better for the ICP-HRMS. For the Ni 437 detection, the situation is different depending on the concentration observed on the GPC 438 chromatogram. The profile obtained for the VR (Figure 6) is sufficient for all the mode tested. 439 The signal to noise ratio is multiplied by a factor of two between the low and medium resolution 440 mode of the ICP-HRMS, but the oxygen mode is even better for the ICP-MS/MS detection. 441 When the hydrotreated feed is observed (Figure 8), the medium resolution is not sensible enough 442 to obtain a clear distribution of the $\mathrm{Ni}$ entities and the use of a low resolution mode is then 443 compulsory. This imply the use of both the medium resolution for $\mathrm{S}$ and $\mathrm{V}$ and the low resolution 444 for Ni in order to obtain the information for all elements, reducing the sample throughput. The 445 use of the ICP-MS/MS in the oxygen mode is sensitive enough to get a nice profile of the $\mathrm{Ni}$ 446 entities on the hydrotreated feed. Such mode is then adequate to have $\mathrm{Ni}, \mathrm{V}$ and $\mathrm{S}$ information 447 during the same run allowing to reduce the analysis cost and time. 


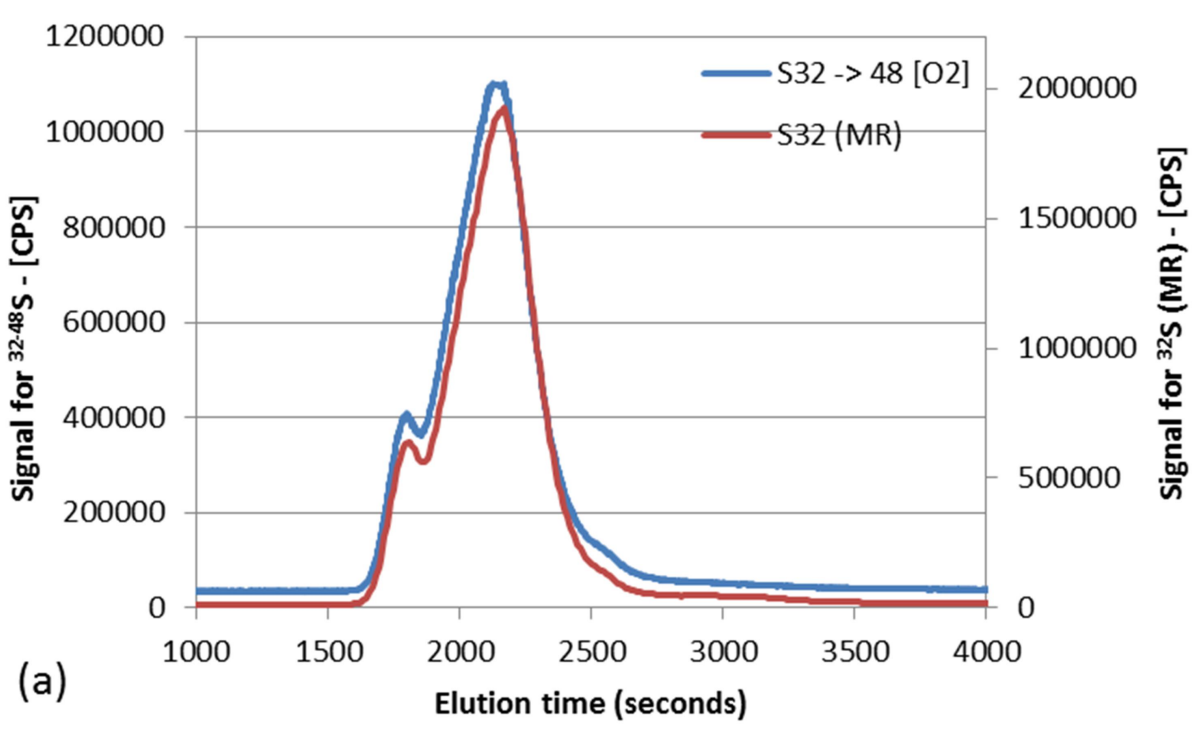

448

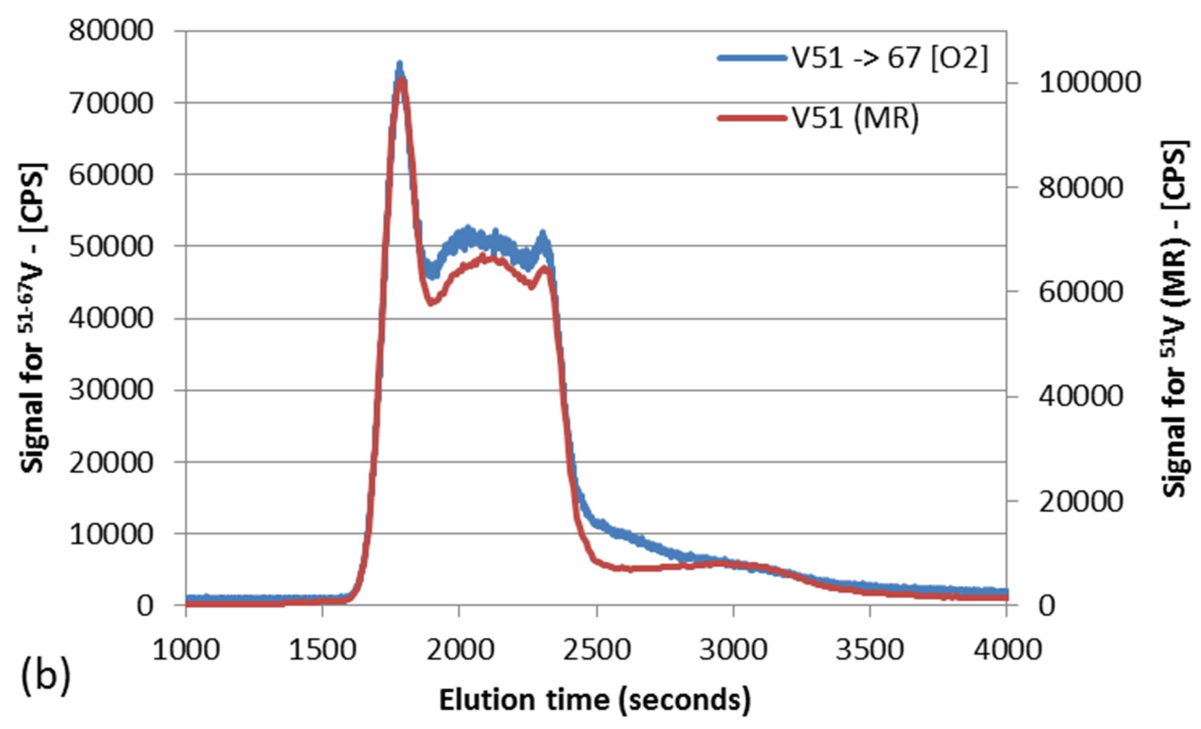

450 Figure 7: Comparison of GPC-ICP-MS/MS and GPC-ICP-HRMS chromatograms for S (a) and V 451 (b) 


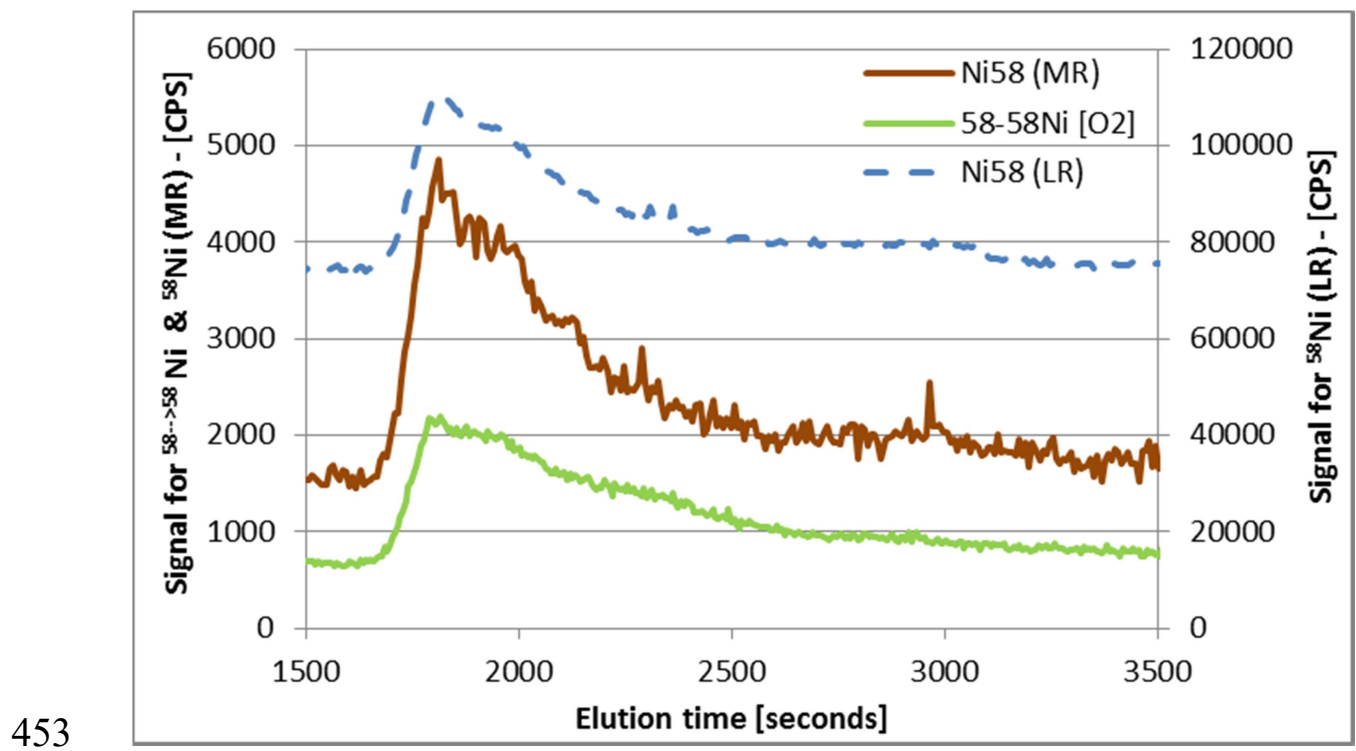

454 Figure 8: Comparison of GPC-ICP-MS/MS and GPC-ICP--HRMS chromatograms for Ni, injecting 455 the HDT VR with Ni content around $3 \mathrm{mg} / \mathrm{kg}$ 


\section{Conclusions}

458 The recent inductively coupled plasma tandem mass spectrometry (ICP-MS/MS) was tested 459 using direct injection of hydrocarbons after solvent dilution in order to investigate its use for the 460 petroleum industry. Based on the fact that many previous authors have used ICP-HRMS for the 461 monitoring of difficult elements in organic matrices, the results obtained for both ICP-MS/MS 462 and ICP-HRMS were compared for both total concentration and speciation of severely interfered 463 isotopes in petroleum products. The capability of ICP-MS/MS to achieve such performance using 464 direct injection of petroleum products after dilution in hydrocarbon solvent was demonstrated 465 here with different applications cases.

466 For the direct determination of heavy elements $(\mathrm{Z}>70)$ in hydrocarbon matrices, the ICP-MS/MS 467 was less sensitive than the ICP-HRMS when the direct introduction of organic substances was 468 used. For light elements $(\mathrm{Z}<40)$, the sensitivity was similar or better using ICP-MS/MS and for 469 interfered elements ( $\mathrm{Si}, \mathrm{S}, \mathrm{Ca}, \mathrm{Fe}$ ), the use of the two quadrupoles combined to the octopole 470 reaction/collision cell (ORC) with $\mathrm{He}, \mathrm{O}_{2}$ or $\mathrm{H}_{2}$ gave similar or better detection limits (LOD) than 471 the ICP-HRMS in medium resolution. The results obtained with the ICP-MS/MS gave good 472 performance with detection limit within the range of $0.004 \mu \mathrm{g} / \mathrm{kg}$ (V) to $0.9 \mu \mathrm{g} / \mathrm{kg}(\mathrm{Al})$ and 473 appeared in the lowest values published in the literature using ICP-MS/MS in organic solvents.

474 Sulfur at very low levels in reformates was successfully monitored in the oxygen mode using the 475 oxide ion $\left({ }^{32} \mathrm{~S} \rightarrow{ }^{48} \mathrm{SO}\right)$. The background equivalent concentration (BEC) origin was attributed to 476 solvent contamination by sulfur and was confirmed by UVF method. Using $\mathrm{He}, \mathrm{O}_{2}$ or $\mathrm{H}_{2}$ as 477 reactant gas, the ICP-MS/MS method easily confirmed Ni and V concentrations measured using 478 wavelength dispersive X-rays fluorescence (WDXRF) and allowed the determination of 14 479 elements in the asphaltene fraction, with concentrations ranging from $0.3 \mathrm{mg} / \mathrm{kg}$ ( $\mathrm{Al}$ and $\mathrm{Pb})$ to $480 \quad 37.4 \mathrm{mg} / \mathrm{kg}$ for Fe.

481 For speciation of $\mathrm{Ni}, \mathrm{V}$ and $\mathrm{S}, \mathrm{GPC}-\mathrm{ICP}-\mathrm{MS} / \mathrm{MS}$ is particularly powerful using $\mathrm{O}_{2}$ both for high 482 (vacuum residue) and low (HDT vacuum residue) contaminated heavy products. Contrary to 483 GPC-ICP-HRMS where two injections of sample were required (medium resolution for S and V 484 and low resolution for Ni), GPC-ICP-MS/MS easily allowed the acquisition of the 3 elements in 485 one mode during the same run and considerably enhancing the sample throughput. This paper 486 clearly demonstrates new opportunities of the ICP-MS/MS in the oil industry using direct 
487 injection of petroleum feedstock's and products after dilution in hydrocarbon solvent for total 488 determination of metals but also for advanced speciation in non-distillable fractions.

489 


\section{Acknowledgments}

491 The help of Leslie Joguet-Valentin and Floriane Lovery (IFPEN, Solaize, France) was very 492 useful for the $\mathrm{S}$ value of the PremiSolv by UVF and the WDXRF value of Ni and V for the 493 asphaltene fraction respectively. 


\section{References}

496 [1] Korn, Maria das Graças Andrade, Santos, Denilson Santana Sodré dos, B. Welz, Vale, Maria Goreti Rodrigues, A.P. Teixeira, Lima, Daniel de Castro, Ferreira, Sérgio Luis Costa, Atomic spectrometric methods for the determination of metals and metalloids in automotive fuels--a review, Talanta 73 (1) (2007) 1-11. https://doi.org/10.1016/j.talanta.2007.03.036.

500 [2] C.P. Lienemann, Analysis of trace metals in petroleum products, state of the art, Oil \& Gas Science and Technology-Revue de 1 Institut Francais du Petrole 60 (6) (2005) 951-965.

[3] R. Sánchez, J.L. Todolí, C.-P. Lienemann, J.-M. Mermet, Determination of trace elements in petroleum products by inductively coupled plasma techniques: A critical review, Spectrochimica Acta Part B: Atomic Spectroscopy 88 (2013) 104-126. https://doi.org/10.1016/j.sab.2013.06.005.

[4] A. Leclercq, A. Nonell, Todolí Torró, José Luis, C. Bresson, L. Vio, T. Vercouter, F. Chartier, Introduction of organic/hydro-organic matrices in inductively coupled plasma optical emission spectrometry and mass spectrometry: a tutorial review. Part II. Practical considerations, Analytica Chimica Acta 885 (2015) 57-91. https://doi.org/10.1016/j.aca.2015.04.039.

[5] P. Dufresne, Hydroprocessing catalysts regeneration and recycling, Applied Catalysis AGeneral 322 (2007) 67-75. https://doi.org/10.1080/01614949608006454.

[6] Palmer S. E., Baker E.W., Science (1978) 49-51.

[7] A. Treibs, On the Chromophores of porphyrin systems, Annals of the New York Academy of Sciences 206 (1973) 97-115. https://doi.org/10.1111/j.1749-6632.1973.tb43207.x.

[8] G. Caumette, C.P. Lienemann, I. Merdrignac, B. Bouyssiere, R. Lobinski, Element speciation analysis of petroleum and related materials, J Anal Atom Spectrom 24 (3) (2009) 263-276. https://doi.org/10.1039/b817888g.

[9] F. Chainet, L. Le Meur, C.-P. Lienemann, J. Ponthus, M. Courtiade, Donard, Olivier François Xavier, Characterization of silicon species issued from PDMS degradation under thermal cracking of hydrocarbons: Part 2 - Liquid samples analysis by a multi-technical approach based on gas chromatography and mass spectrometry, Fuel 116 (2014) 478-489. https://doi.org/10.1016/j.fuel.2013.08.010. 
[10] B. Didillon, J. Cosyns, C. Cameron, D. Uzio, P. Sarrazin, J.P. Boitiaux, Industrial evaluation of selective hydrogenation catalyst poisoning, Catalyst Desactivation 1997111 (1997) 447454. https://doi.org/10.2516/ogst:2007006.

[11] A. Doyle, A. Saavedra, M.L.B. Tristão, R.Q. Aucelio, Determination of S, Ca, Fe, Ni and V in crude oil by energy dispersive X-ray fluorescence spectrometry using direct sampling on paper substrate, Fuel 162 (2015) 39-46. https://doi.org/10.1016/j.fuel.2015.08.072.

[12] A. Cinosi, N. Andriollo, G. Pepponi, D. Monticelli, A novel total reflection X-ray fluorescence procedure for the direct determination of trace elements in petrochemical products, Anal Bioanal Chem 399 (2) (2011) 927-933. https://doi.org/10.1007/s00216-0104352-x.

[13] J. Nelson, G. Gilleland, L. Poirier, D. Leong, P. Hajdu, F. Lopez-Linares, Elemental Analysis of Crude Oils Using Microwave Plasma Atomic Emission Spectroscopy, Energy \& Fuels 29 (9) (2015) 5587-5594. https://doi.org/10.1021/acs.energyfuels.5b01026.

[14] A. Harhira, J. El Haddad, A. Blouin, M. Sabsabi, Rapid Determination of Bitumen Content in Athabasca Oil Sands by Laser-Induced Breakdown Spectroscopy, Energy Fuels 32 (3) (2018) 3189-3193. https://doi.org/10.1021/acs.energyfuels.7b03821.

[15] L. Poirier, J. Nelson, D. Leong, L. Berhane, P. Hajdu, F. Lopez-Linares, Application of ICPMS and ICP-OES on the Determination of Nickel, Vanadium, Iron, and Calcium in Petroleum Crude Oils via Direct Dilution, Energy Fuels 30 (5) (2015) 3783-3790. https://doi.org/10.1021/acs.energyfuels.5b02997.

[16] S. Dreyfus, C. Pecheyran, C. Magnier, A. Prinzhofer, C.P. Lienemann, O.F.X. Donard, Direct trace and ultra-trace metals determination in crude oil and fractions by inductively coupled plasma mass spectrometry, Elemental Analysis of Fuels and Lubricants: Recent Advances and Future Prospects 1468 (2005) 51-58.

[17] G. Caumette, C.-P. Lienemann, I. Merdrignac, B. Bouyssiere, R. Lobinski, Fractionation and speciation of nickel and vanadium in crude oils by size exclusion chromatography-ICP MS and normal phase HPLC-ICP MS, J Anal Atom Spectrom 25 (7) (2010) 1123. https://doi.org/10.1039/c003455j.

[18] F. Chainet, C.-P. Lienemann, J. Ponthus, C. Pécheyran, J. Castro, E. Tessier, Donard, Olivier François Xavier, Towards silicon speciation in light petroleum products using gas chromatography coupled to inductively coupled plasma mass spectrometry equipped with a 
dynamic reaction cell, Spectrochimica Acta Part B: Atomic Spectroscopy 97 (2014) 49-56. https://doi.org/10.1016/j.sab.2014.04.010.

[19] R. Sánchez, J.L. Todolí, C.-P. Lienemann, J.-M. Mermet, Universal calibration for metal determination in fuels and biofuels by inductively coupled plasma atomic emission spectrometry based on segmented flow injection and a $350{ }^{\circ} \mathrm{C}$ heated chamber, J Anal Atom Spectrom 27 (6) (2012) 937. https://doi.org/10.1039/c2ja10336b.

[20] A. Leclercq, A. Nonell, Todolí Torró, José Luis, C. Bresson, L. Vio, T. Vercouter, F. Chartier, Introduction of organic/hydro-organic matrices in inductively coupled plasma optical emission spectrometry and mass spectrometry: A tutorial review. Part I. Theoretical considerations, Analytica Chimica Acta 885 (2015) 33-56. https://doi.org/10.1016/j.aca.2015.03.049.

[21] P. Pohl, N. Vorapalawut, B. Bouyssiere, H. Carrier, R. Lobinski, Direct multi-element analysis of crude oils and gas condensates by double-focusing sector field inductively coupled plasma mass spectrometry (ICP MS), J Anal Atom Spectrom 25 (5) (2010) 704. https://doi.org/10.1039/c000658k.

[22] J. Heilmann, S.F. Boulyga, K.G. Heumann, Development of an isotope dilution laser ablation ICP-MS method for multi-element determination in crude and fuel oil samples, J. Anal. At. Spectrom. 24 (4) (2009) 385-390. https://doi.org/10.1039/B819879A.

[23] A. Desprez, B. Bouyssiere, C. Arnaudguilhem, G. Krier, L. Vernex-Loset, P. Giusti, Study of the Size Distribution of Sulfur, Vanadium, and Nickel Compounds in Four Crude Oils and Their Distillation Cuts by Gel Permeation Chromatography Inductively Coupled Plasma High-Resolution Mass Spectrometry, Energy \& Fuels 28 (6) (2014) 3730-3737. https://doi.org/10.1021/ef500571f.

[24] S. Gutierrez Sama, A. Desprez, G. Krier, C.-P. Lienemann, J. Barbier, R. Lobinski, C. Barrere-Mangote, P. Giusti, B. Bouyssiere, Study of the Aggregation of Metal Complexes with Asphaltenes Using Gel Permeation Chromatography Inductively Coupled Plasma HighResolution Mass Spectrometry, Energy Fuels 30 (9) (2016) 6907-6912. https://doi.org/10.1021/acs.energyfuels.6b00559.

[25] L. Balcaen, E. Bolea-Fernandez, M. Resano, F. Vanhaecke, Inductively coupled plasma Tandem mass spectrometry (ICP-MS/MS): A powerful and universal tool for the 
interference-free determination of (ultra)trace elements - A tutorial review, Analytica Chimica Acta 894 (2015) 7-19. https://doi.org/10.1016/j.aca.2015.08.053.

[26] L. Balcaen, G. Woods, M. Resano, F. Vanhaecke, Accurate determination of S in organic matrices using isotope dilution ICP-MS/MS, J. Anal. At. Spectrom. 28 (1) (2013) 33-39. https://doi.org/10.1039/c2ja30265a.

[27] R.S. Amais, Amaral, Clarice D. B., L.L. Fialho, D. Schiavo, J.A. Nóbrega, Determination of $\mathrm{P}, \mathrm{S}$ and $\mathrm{Si}$ in biodiesel, diesel and lubricating oil using ICP-MS/MS, Anal. Methods 6 (13) (2014) 4516. https://doi.org/10.1039/c4ay00279b.

[28] E. Bolea-Fernandez, L. Balcaen, M. Resano, F. Vanhaecke, Overcoming spectral overlap via inductively coupled plasma-tandem mass spectrometry (ICP-MS/MS). A tutorial review, J. Anal. At. Spectrom. 32 (9) (2017) 1660-1679. https://doi.org/10.1039/C7JA00010C.

[29] Tomoko Vincent, Determination of ultratrace elements in photoresist solvents using the Thermo Scientific iCAP TQs ICP-MS (Application note 43374), 2018 (accessed 15 November 2018).

[30] Y. Kitamanki, Y. Zhu, M. Numata, Accurate Characterization of Sulfur in Biodiesel Fuel Certified Reference Material, J. Jpn. Petrol. Inst. 59 (6) (2016) 317-321. https://doi.org/10.1627/jpi.59.317.

[31] C. Walkner, R. Gratzer, T. Meisel, S.N.H. Bokhari, Multi-element analysis of crude oils using ICP-QQQ-MS, Organic Geochemistry 103 (2017) 22-30. https://doi.org/10.1016/j.orggeochem.2016.10.009.

[32] W. Yang, J.F. Casey, Y. Gao, A new sample preparation method for crude or fuel oils by mineralization utilizing single reaction chamber microwave for broader multi-element analysis by ICP techniques, Fuel 206 (2017) 64-79. https://doi.org/10.1016/j.fuel.2017.05.084.

[33] A. Vetere, D. Pröfrock, W. Schrader, Quantitative and Qualitative Analysis of Three Classes of Sulfur Compounds in Crude Oil, Angew. Chem. Int. Ed Engl. 56 (36) (2017) 1093310937. https://doi.org/10.1002/anie.201703205.

[34] F. Chainet, L. Le Meur, C.-P. Lienemann, M. Courtiade, J. Ponthus, L. Brunet-Errard, Donard, Olivier François Xavier, Degradation processes of polydimethylsiloxane under thermal cracking conditions of hydrocarbons in an experimental pilot plant followed by size exclusion chromatography coupled to inductively coupled plasma high resolution mass 
spectrometry, Fuel Processing Technology 104 (2012) 300-309. https://doi.org/10.1016/j.fuproc.2012.05.029.

618 [35] J. Barbier, J. Marques, G. Caumette, I. Merdrignac, B. Bouyssiere, R. Lobinski, C.-P. Lienemann, Monitoring the behaviour and fate of nickel and vanadium complexes during vacuum residue hydrotreatment and fraction separation, Fuel Processing Technology 119 (2014) 185-189. https://doi.org/10.1016/j.fuproc.2013.11.004.

[36] P. Giusti, Y.N. Ordonez, C.P. Lienemann, D. Schaumloffel, B. Bouyssiere, R. Lobinski, $\mu-$ Flow-injection-ICP collision cell MS determination of molybdenum, nickel and vanadium in petroleum samples using a modified total consumption micronebulizer, J Anal Atom Spectrom 22 (1) (2007) 88-92.

[37] V. Thomsen, D. Schatzlein, D. Mercuro, Limits of detection in spectroscopy, Spectroscopy 18 (12) (2003) 112-114.

[38] R.H. Filby, S.D. Olsen, A comparison of instrumental neutron activation analysis and inductively coupled plasma-mass spectrometry for trace element determination in petroleum geochemistry, journal of Radioanalytical and Nuclear Chemistry 180 (1994) 285-294.

[39] C. Duyck, N. Miekeley, Porto da Silveira, Carmem L., P. Szatmari, Trace element determination in crude oil and its fractions by inductively coupled plasma mass spectrometry using ultrasonic nebulization of toluene solutions, Spectrochimica Acta Part B: Atomic 
638 Table 1: Characteristics of the petroleum cuts provided for the various experiments. 8

639 Table 2: Operating conditions for total analysis using ICP-MS apparatus ..................................10

640 Table 3: BEC $[\mu \mathrm{g} / \mathrm{kg}]$ of ${ }^{32 \rightarrow 48} \mathrm{~S}$ obtained for each solvent and plasma conditions.....................19

641 Table 4: Concentration obtained by WDXRF and ICP-MS/MS for the asphaltene fraction .........21

643 Figure 1: Comparison of detection limits obtained using diameters 1.0 and $1.5 \mathrm{~mm}$ for two 644 injectors proposed for the ICP-MS/MS

645 Figure 2: Calibration curves for S using ICP-HRMS or ICP-MS/MS (Arrows indicate the correct 646 axis for all calibration curves) .14

647 Figure 3: Calibration curves for Si using ICP-HRMS or ICP-MS/MS (Arrows indicate the correct

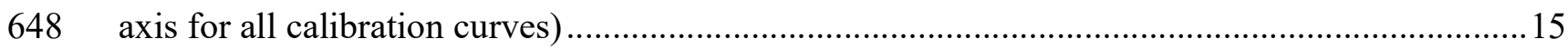

649 Figure 4: Calibration curves for Fe using ICP-HRMS or ICP-MS/MS .................................... 15

650 Figure 5: Comparison of Background Equivalent Concentration (a) and Limit of Detection (b) for 651 various elements between ICP-HRMS and ICP-MS/MS detection. .17

652 Figure 6: Comparison of GPC-ICP-MS/MS and GPC-ICP-HRMS chromatograms for Ni, 653 injecting a VR with Ni content around $60 \mathrm{mg} / \mathrm{kg}$ .22

654 Figure 7: Comparison of GPC-ICP-MS/MS and GPC-ICP-HRMS chromatograms for S (a) and V 655 (b) 24

656 Figure 8: Comparison of GPC-ICP-MS/MS and GPC-ICP--HRMS chromatograms for Ni, 657 injecting the HDT VR with Ni content around $3 \mathrm{mg} / \mathrm{kg}$ .25 658

659 Figure S 1: Calibration curves for Ni $\left({ }^{58 \rightarrow 58} \mathrm{Ni}\right.$ and $\left.{ }^{60 \rightarrow 60} \mathrm{Ni}\right)$ and V using ICP-HRMS or ICP$660 \mathrm{MS} / \mathrm{MS}$ (Arrows indicate the correct axis for all calibration curves) .36 661 
$663 \quad 8$ Supplementary material

664

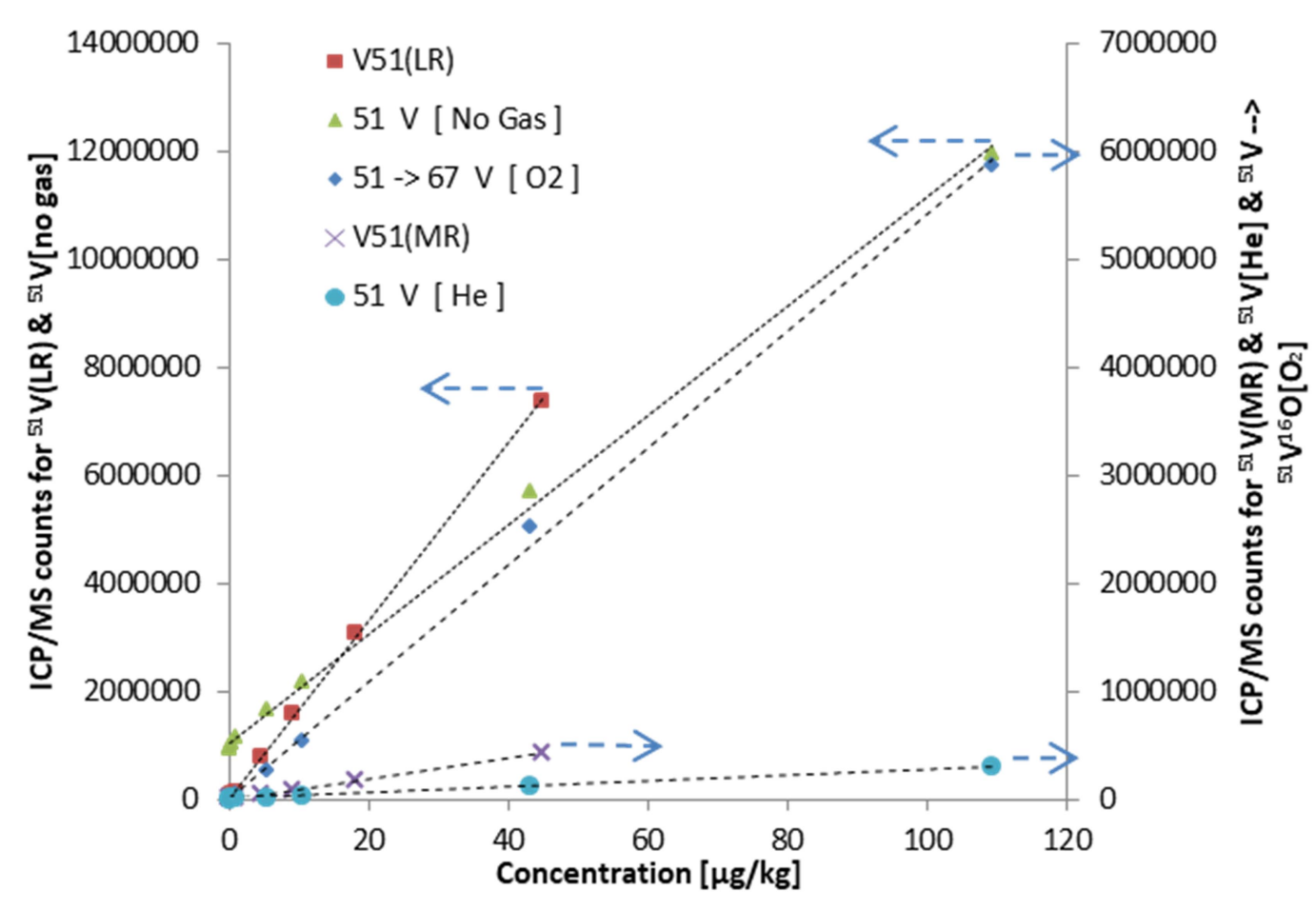

665

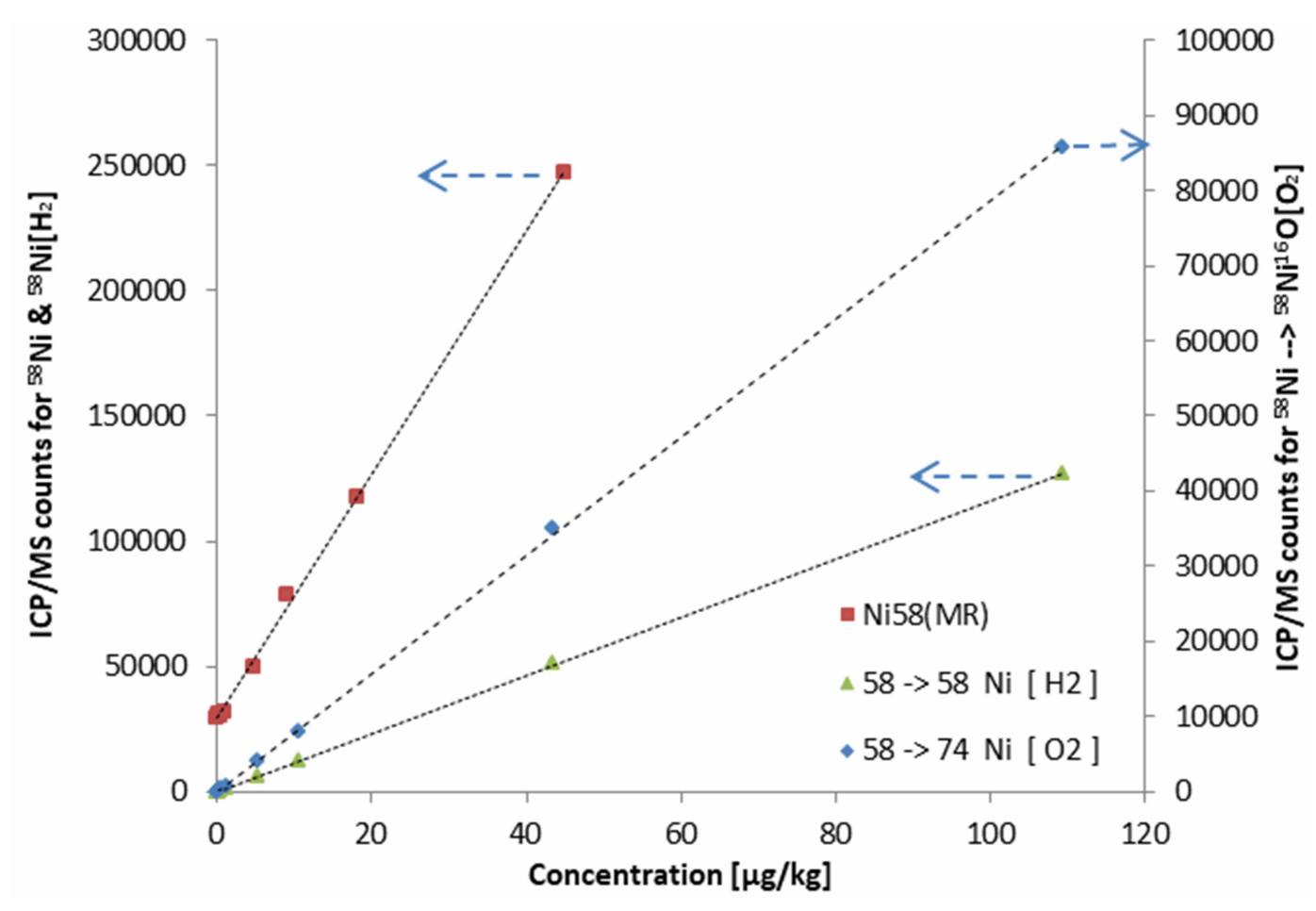




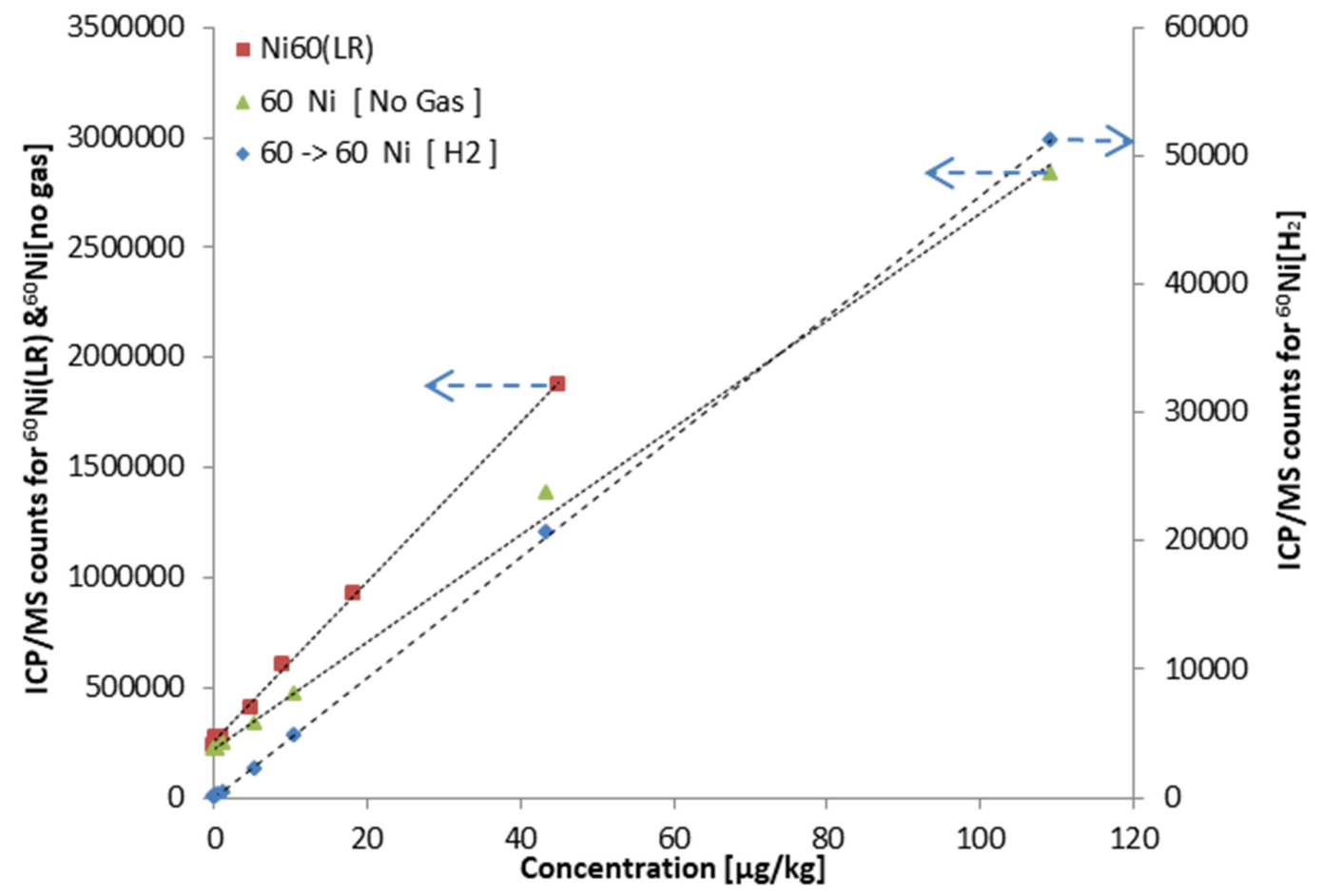

669 Figure S 1: Calibration curves for $\mathrm{Ni}\left({ }^{58 \rightarrow 58} \mathrm{Ni}\right.$ and $\left.{ }^{60 \rightarrow 60} \mathrm{Ni}\right)$ and $\mathrm{V}$ using ICP-HRMS or ICP-MS/MS 670 (Arrows indicate the correct axis for all calibration curves) 